\title{
Proteomic Analysis Uncovers Novel Actions of the Neurosecretory Protein VGF in Nociceptive Processing
}

\author{
Maureen S. Riedl, ${ }^{1}$ Patrick D. Braun, ${ }^{1,2}$ Kelley F. Kitto, ${ }^{1,2,3}$ Samuel A. Roiko, ${ }^{3}$ Lorraine B. Anderson, ${ }^{4}$ \\ Christopher N. Honda, ${ }^{1}$ Carolyn A. Fairbanks, ${ }^{1,2,3}$ and Lucy Vulchanova ${ }^{5}$ \\ Departments of ${ }^{1}$ Neuroscience, ${ }^{2}$ Pharmaceutics, ${ }^{3}$ Pharmacology, and ${ }^{4}$ Biochemistry, Molecular Biology, and Biophysics, University of Minnesota, \\ Minneapolis, Minnesota 55455, and ${ }^{5}$ Department of Veterinary and Biomedical Sciences, University of Minnesota, St. Paul, Minnesota 55108
}

\begin{abstract}
Peripheral tissue injury is associated with changes in protein expression in sensory neurons that may contribute to abnormal nociceptive processing. We used cultured dorsal root ganglion (DRG) neurons as a model of axotomized neurons to investigate early changes in protein expression after nerve injury. Comparing protein levels immediately after DRG dissociation and $24 \mathrm{~h}$ later by proteomic differential expression analysis, we found a substantial increase in the levels of the neurotrophin-inducible protein VGF (nonacronymic), a putative neuropeptide precursor. In a rodent model of nerve injury, VGF levels were increased within $24 \mathrm{~h}$ in both injured and uninjured DRG neurons, and the increase persisted for at least $7 \mathrm{~d}$. VGF was also upregulated $24 \mathrm{~h}$ after hindpaw inflammation. To determine whether peptides derived from proteolytic processing of VGF participate in nociceptive signaling, we examined the spinal effects of AQEE-30 and LQEQ-19, potential proteolytic products shown previously to be bioactive. Each peptide evoked dose-dependent thermal hyperalgesia that required activation of the mitogen-activated protein kinase $\mathrm{p} 38$. In addition, LQEQ-19 induced p38 phosphorylation in spinal microglia when injected intrathecally and in the BV-2 microglial cell line when applied in vitro. In summary, our results demonstrate rapid upregulation of VGF in sensory neurons after nerve injury and inflammation and activation of microglial p38 by VGF peptides. Therefore, VGF peptides released from sensory neurons may participate in activation of spinal microglia after peripheral tissue injury.
\end{abstract}

\section{Introduction}

Sensory neurons respond to peripheral tissue damage, such as nerve injury or inflammation, with changes in protein expression and functional properties that contribute to altered nociceptive processing in the spinal cord (Woolf and Costigan, 1999; Campbell and Meyer, 2006; White et al., 2007). Spinal microglia participate in the development of inflammatory and nerve injuryinduced hypersensitivity through mechanisms mediated in part by the mitogen-activated protein kinase (MAPK) p38 (Jin et al., 2003; Svensson et al., 2003; Raghavendra et al., 2004; Tsuda et al., 2004, 2005; Boyle et al., 2006). Within sensory neurons, changes in expression levels have been reported for a number of signaling mediators, including neuropeptides, neurotrophins, and chemokines (Fukuoka et al., 1998; Woolf and Costigan, 1999; Karchewski et al., 2002; Zhang and De Koninck, 2006). The upregulation of signaling mediators released from sensory neurons in spinal cord may contribute to microglial activation within the dorsal horn after peripheral tissue damage.

Received March 9, 2009; revised July 15, 2009; accepted Aug. 10, 2009.

This work was supported by National Institute on Drug Abuse/National Institutes of Health Grants K01 DA017236 (L.V.) and T32 DA07234 (P.D.B.). We thank Galina Kalyuzhnaya and Kristin Krebs for technical assistance, Dr. Jonathan Godbout for his kind gift from BV-2 cells, and Drs. Robert Elde, Alice Larson, Virginia Seybold, and Laura Stone for valuable insights. We are also grateful to Dr. LeeAnn Higgins and the Center for Mass Spectrometry and Proteomics for assistance with proteomic data collection.

Correspondence should be addressed to Lucy Vulchanova, Department of Veterinary and Biomedical Sciences, University of Minnesota, 295 AS/VM, 1988 Fitch Avenue, St. Paul, MN 55108. E-mail: vulch001@umn.edu. DOI:10.1523/JNEUROSCI.1127-09.2009

Copyright $\odot 2009$ Society for Neuroscience ～0270-6474/09/2913377-12\$15.00/0
In this study, we used cultured adult dorsal root ganglia (DRG) as a model system of axotomized neurons to investigate early changes in protein expression after nerve injury. Relative quantitation of protein levels was done using iTRAQ (for isobaric tag for relative and absolute quantitation), a mass spectrometrybased method for proteomic differential expression analysis (Li et al., 2007; Lund et al., 2007). Among the proteins identified as upregulated in this analysis, we selected for additional study the neurosecretory protein VGF (nonacronymic) based on evidence that its expression is induced by neuronal lesions and neurotrophins (Levi et al., 2004). VGF, a 617 aa protein related to the chromogranins, has the characteristics of a neuropeptide precursor, but the precise identities of bioactive VGF-derived peptides and the putative receptors that mediate their action are unknown. VGF has been implicated in neuroplasticity associated with depression as well as learning and memory, and, in cultured hippocampal neurons, VGF-derived peptides potentiated synaptic activity (Alder et al., 2003; Hunsberger et al., 2007; ThakkerVaria et al., 2007; Bozdagi et al., 2008). In this study, we addressed the hypotheses that VGF is upregulated in sensory neurons after peripheral tissue injury and that VGF-derived peptides have pronociceptive spinal effects. Our results demonstrate rapid VGF upregulation after nerve injury and inflammation and show that VGF-derived peptides evoke p38-dependent thermal hyperalgesia and p38 activation in microglial cells.

\section{Materials and Methods}

All procedures conform to guidelines of the National Institutes of Health Guide for the Care and Use of Laboratory Animals and were approved by the 
Institutional Animal Care and Use Committee of the University of Minnesota.

\section{$D R G$ cultures}

Primary cultures of rat DRG neurons were prepared using methods similar to those described previously (Khasabova et al., 2004). Briefly, DRG were isolated from all spinal levels of four adult male rats (125-200 g, Sprague Dawley; Harlan), enzymatically dissociated in collagenase-D $(1.5 \mathrm{mg} / \mathrm{ml}$, two 45 min incubations; Roche Diagnostics) and triturated through fire-constricted Pasteur pipettes. For proteomic and Western blot analysis, all cells from one rat were divided in half and plated in two $10 \mathrm{~cm}$ glass Petri dishes coated with poly-L-lysine ( $10 \mu \mathrm{g} / \mathrm{ml}$; SigmaAldrich) and laminin (10 $\mu \mathrm{g} / \mathrm{ml}$; SigmaAldrich) in F-12/Ham's medium containing $10 \%$ fetal bovine serum (plating density, $50,000-80,000$ cells per dish). Cells from one of the dishes were harvested $\sim 1.5 \mathrm{~h}$ after plating $\left(t_{0}\right)$, and cells from the other dish were harvested $24 \mathrm{~h}$ later $\left(t_{24}\right)$. For immunohistochemistry, glass coverslips were placed into $10 \mathrm{~cm}$ glass Petri dishes before coating with poly-L-lysine and laminin and removed either $1.5 \mathrm{~h}\left(t_{0}\right)$ or $24 \mathrm{~h}\left(t_{24}\right)$ after plating, rinsed twice with PBS, incubated for $20 \mathrm{~min}$ in fixative ( $4 \%$ paraformaldehyde and $0.2 \%$ picric acid in $0.1 \mathrm{M}$ phosphate buffer, $\mathrm{pH} 6.9$ ), and rinsed in three changes of PBS before proceeding with immunohistochemistry.

\section{Proteomic analysis of DRG cultures}

Cells were washed with PBS and detached by gentle pipetting of the buffer and agitation at $4^{\circ} \mathrm{C}$. Recovery of neurons was verified visually. The cells were collected by centrifugation at $3000 \times g$ for $15 \mathrm{~min}$, frozen in liquid nitrogen, and stored until sample preparation. The cells were separated into subcellular fractions using ProteoExtract Subcellular Proteome Extraction kit (Calbiochem), and the proteins in the cytoplasmic and nuclear fractions were prepared for mass spectrometric analysis by precipitation using cold acetone. Proteins from the cytoplasmic and nuclear fractions of both time points were denatured, reduced and cysteine alkylated before digestion with trypsin, and labeled with the iTRAQ reagents (Applied Biosystems) following the directions of the manufacturer. The labeled tryptic peptides in the four samples $\left(114, t_{0}\right.$ cytoplasmic fraction; $115, t_{24}$ cytoplasmic fraction; $116, t_{0}$ nuclear fraction; and $117, t_{24}$ nuclear fraction) were combined and separated by two-dimensional liquid chromatography (2D LC) using strong cation exchange on a Magic 2002 HPLC system (Michrom BioResourses), followed by C18 reverse-phase LC (Dionex/LC Packings capillary LC system) online with a QSTAR Pulsar $i$ Mass Spectrometer (Applied Biosystems) as described by Lund et al. (2007). The tandem mass spectrometry (MS/MS) data were analyzed using ProteinPilot Software 2.0.1 (Applied Biosystems/MDS Sciex) with the Paragon Algorithm (Shilov et al., 2007) and searched against a nonredundant database of human, mouse, and rat proteins compiled from National Center for Biotechnology Information on March 9, 2007 that included common contaminants (59,817 total proteins) for the identification and quantification of proteins. ProteinPilot assigns confidence of protein identification based on the highest confidence peptide used to identify the protein, and peptide confidence is a measure of sequence accuracy determined by MS/MS sequence coverage and the number of other potential sequence matches. The resulting set of identified proteins, which included corresponding gene identifiers and expression values, was uploaded into Ingenuity Pathways Analysis (IPA) (Ingenuity Systems) and annotated. Each gene identifier was mapped to its corresponding gene object in the Ingenuity Pathways Knowledge Base. Additional analysis was focused on proteins with iTRAQ ratios $>2$. For proteins with ratios that showed more than a twofold increase but were identified with $<95 \%$ confidence, the identification was

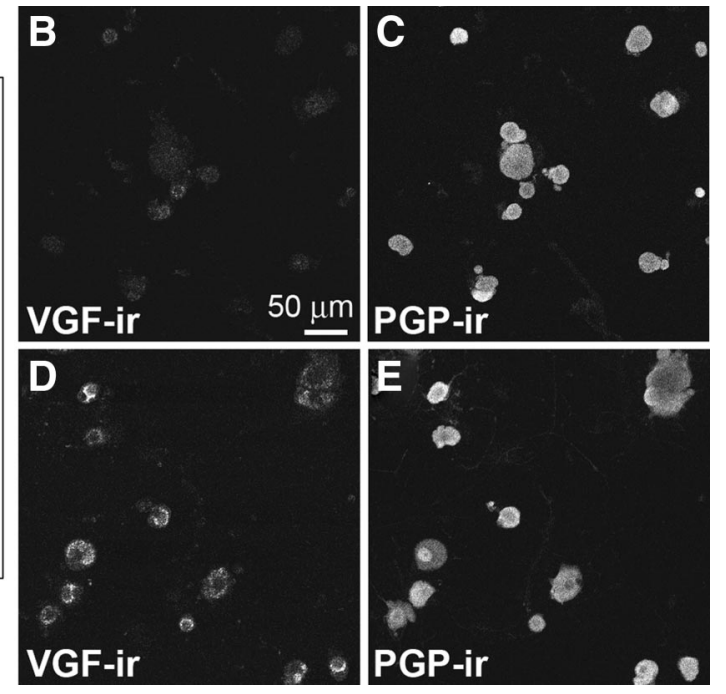

Figure 1. Upregulation of VGF immunoreactivity in cultured DRG neurons. $\boldsymbol{A}$, In Western blot analysis, samples from $t_{24} \mathrm{DRG}$ cultures show a band at $\sim 90 \mathrm{kDa}$, which corresponds to the unprocessed form of VGF. The lower-molecular-weight bands most

confirmed by manual inspection of the peptide spectra. In addition, ratios with $p>0.05$ (assigned by ProteinPilot) were verified by manual inspection of the iTRAQ reporter regions fragmented from the peptides.

Western blot analysis of DRG cultures

Cells were homogenized for $5 \mathrm{~s}$ on ice in extraction buffer (TBS, pH 7.4, $1 \%$ Triton X-100, 10 mm EDTA, and $10 \mathrm{~mm}$ EGTA) in the presence of protease inhibitors (Complete Mini, EDTA-free; Roche) using a glass homogenizer. The supernatant was collected and mixed with $4 \times$ loading buffer (3:1 sample/loading buffer; NuPage; Invitrogen), heated for 10 min at $70^{\circ} \mathrm{C}$, and loaded into wells of $4-12 \%$ Bis-Tris gels (NuPage; Invitrogen). The gels underwent electrophoresis at constant voltage (160 $\mathrm{V})$ for $1 \mathrm{~h}$, and proteins were transferred from the gel onto polyvinylidene fluoride membranes for $1 \mathrm{~h}$ using constant amperage $(250 \mathrm{~mA})$. The membranes were incubated as follows: (1) in blocking buffer [TBS, $\mathrm{pH}$ 7.4, containing 0.2\% I-Block reagent (Applied Biosystems) and 0.1\% Tween 20] overnight at $4^{\circ} \mathrm{C}$; (2) in anti-VGF primary antisera $(1: 10,000$; generated in house as described below) overnight at $4^{\circ} \mathrm{C}$; (3) washed four times for $30 \mathrm{~min}$ in blocking buffer; (4) in horseradish peroxidaseconjugated secondary antibodies (1:10,000; Jackson ImmunoResearch) at room temperature for $2 \mathrm{~h}$; (5) washed four times for $30 \mathrm{~min}$ in TBS containing $0.1 \%$ Tween 20 and two times for $30 \mathrm{~min}$ in TBS; and (6) in chemiluminescent substrate (Pierce Supersignal) for $5 \mathrm{~min}$. The membranes were then exposed to Kodak X-O-Mat Blue film (Eastman Kodak).

\section{Models of persistent pain}

Spinal nerve ligation. Spinal nerve ligation (SNL) was performed on adult male Sprague Dawley rats (150-200 g; Harlan) similar to previously described procedures (Kim and Chung, 1992). Under isoflurane anesthesia, the left L5 transverse process was exposed and removed, and the L5 spinal nerve was tightly ligated with 6-0 silk suture. Sham surgery consisted of removal of the transverse process and visualization of the L5 spinal nerve without touching it. Induction of hypersensitivity was measured using von Frey filaments and the up-down method as described previously (Chaplan et al., 1994). Animals were killed by perfusion fixation 1,3 , or $7 \mathrm{~d}$ after surgery.

Inflammation. Complete Freund's adjuvant (CFA) inflammation was induced as described previously (Wenk et al., 2006). Under isoflurane anesthesia, $100 \mu \mathrm{l}$ of CFA (1:1 emulsion in saline; Sigma) was injected subcutaneously into the plantar surface of the right hindpaw of adult male Sprague Dawley rats (150-200 g; Harlan). The animals were killed by perfusion fixation $24 \mathrm{~h}$ after CFA injection. 
Table 1. Proteins showing more than twofold increase at $t_{24}$ compared with $t_{0}$

\begin{tabular}{|c|c|c|}
\hline Protein name & Fold increase & Potential functional relevance \\
\hline \multicolumn{3}{|l|}{ Oxidative stress } \\
\hline Ferritin heavy polypeptide 1 & $6.68^{*}$ & Protective during oxidative stress (Chiba et al., 2007). \\
\hline Thioredoxin reductase 1 & $2.64^{\#}$ & Protective during oxidative stress (Xia et al., 2003); upregulated in DRG at $14 \mathrm{~d}$ in a model of HIV neuropathy (Maratou et al., 2009) \\
\hline Prothymosin $\alpha$ & $2.56^{*}$ & $\begin{array}{l}\text { Regulates apoptosis and oxidative stress (Karapetian et al., 2005; Fujita and Ueda, 2007); upregulated in DRG } 14 \mathrm{~d} \text { after SNT } \\
\text { (Maratou et al., 2009). }\end{array}$ \\
\hline \multicolumn{3}{|l|}{ Membrane-cytoskeletal signaling } \\
\hline $\begin{array}{l}\text { Myristoylated alanine-rich C-kinase } \\
\text { substrate-like 1, MARCKSL1 }\end{array}$ & $2.12^{\#}$ & Protein kinase C (PKC) substrate, which binds actin, calmodulin, and acidic phospholipids. \\
\hline $\begin{array}{l}\text { Brain abundant membrane attached } \\
\text { signal protein } 1 \text { (BASP1/CAP-23) }\end{array}$ & $2.28^{\# \#}$ & $\begin{array}{l}\text { PKC substrate, which binds actin, calmodulin, and acidic phospholipids; upregulated in DRG 3, 6, and } 14 \mathrm{~d} \text { after sciatic nerve crush } \\
\text { (Mason et al., 2002). }\end{array}$ \\
\hline Gravin/A kinase anchor protein (AKAP12) & $2.68^{\#}$ & Scaffold protein that interacts with PKA, PKC, and actin; expressed in unmyelinated sensory neurons (Irmen et al., 2008). \\
\hline Tropomyosin 4 & $2.17^{\# \# \#}$ & $\begin{array}{l}\text { Neuronal tropomyosin found in growth cones and presynaptic terminals (Had et al., 1994); upregulated } 7 \mathrm{~d} \text { after SNL (Komori et al. } \\
\text { 2007). }\end{array}$ \\
\hline Thymosin $\beta 4$ & $2.03^{\# \# \#}$ & $\begin{array}{l}\text { Actin-sequestering protein; promotes wound healing and repair after hypoxia (Goldstein et al., 2005); upregulated in DRG } 14 \mathrm{~d} \\
\text { after SNT (Maratou et al., 2009). }\end{array}$ \\
\hline \multicolumn{3}{|l|}{ Transcription regulation } \\
\hline APEX nuclease & $3.95^{\#}$ & DNA repair and regulation of transcription factors (Vasko et al., 2005; Qu et al., 2007). \\
\hline Y box binding protein 1 (YBX1) & $3.27^{\#}$ & Transcription factor and translation regulator (Kohno et al., 2003); upregulated in DRG $14 \mathrm{~d}$ after SNT (Maratou et al., 2009). \\
\hline \multicolumn{3}{|l|}{ Neuropeptide signaling } \\
\hline CGRP precursor & $5.19^{*}$ & CGRP is expressed in nociceptive sensory neurons. Complex regulation in nerve injury, see Discussion. \\
\hline Neurosecretory protein VGF & $45.35^{\#}$ & $\begin{array}{l}\text { Putative precursor of signaling peptides; upregulated } 3 \mathrm{~d} \text { after sciatic nerve axotomy and } 14 \mathrm{~d} \text { after SNL (Costigan et al., 2002; } \\
\text { Wang et al., 2002; Valder et al., 2003). }\end{array}$ \\
\hline \multicolumn{3}{|l|}{ Other } \\
\hline Diazepam binding inhibitor (DBI) & $2.33^{*}$ & $\begin{array}{l}\text { Stimulation of steroid synthesis. DBI expressed in satellite cells, expression not altered } 3 \mathrm{~d} \text { after sciatic nerve transection } \\
\text { (Karchewski et al., 2004); upregulated in DRG } 14 \mathrm{~d} \text { after SNT (Maratou et al., 2009). }\end{array}$ \\
\hline Proteasome P20 subunit (PSMB7) & $2.13^{\#}$ & Protein degradation. Proteasome activity affects nerve injury induced hypersensitivity (Moss et al., 2003; Ossipov et al., 2007). \\
\hline$\alpha$-Galactosidase & $2.21^{\# \#}$ & $\begin{array}{l}\text { Glycolipid and glycoprotein degradation. Mutations associated with Fabry's disease. Downregulated in DRG } 14 \mathrm{~d} \text { after SNT } \\
\text { (Maratou et al., 2009). }\end{array}$ \\
\hline Palmytoyl-protein thioesterase 1 & $2.38^{\#}$ & Lysosomal enzyme involved in degradation of lipoproteins. Mutations associated with neurodegeneration (Gardiner, 2000). \\
\hline Acetyl-coenzyme $A$ acetyltransferase 2 & $2.68^{\# \#}$ & Peroxysomal enzyme involved in fatty acid metabolism. \\
\hline $\begin{array}{l}\text { Cell cycle exit and neuronal } \\
\text { differentiation } 1 \text { (CEND1) }\end{array}$ & $2.87^{\# \#}$ & Function described by Politis et al. (2007). \\
\hline $\begin{array}{l}\text { LSM3 homolog, U6 small nuclear RNA } \\
\text { associated }\end{array}$ & $2.12^{\#}$ & Upregulated in DRG 14 d after SNT (Maratou et al., 2009). Function described by Beggs (2005). \\
\hline
\end{tabular}

Proteins showing more than twofold increase at $t_{24}$ compared with $t_{0}$. Relative protein abundance was determined using iTRAQ combined with $2 D$ LC-MS/MS. Fold increase was determined from ratios of individual peptides assigned to each protein by ProteinPilot. Ratios calculated from three or more peptides and with $p<0.05$ are indicated by asterisk (*). For ratios with $p>0.05$, the data was verified by manual inspection as described in Materials and Methods. The table includes ratios obtained from a single peptide (indicated by \#) or the average of two (\#\#) or more (\#\#) peptides.

${ }^{a}$ SNT, L5 spinal nerve transection.

\section{VGF peptides}

The following VGF-derived peptides were used in this study: AQEE-30, corresponding to the last 30 aa $(588-A Q E E A D A E E R$ RLQEQEELENYIEHVLLHRP617) of the VGF protein; AQEE-11, corresponding to the first 11 aa of AQEE-30; and LQEQ-19, corresponding to the last 19 aa of AQEE-30. The peptides were individually synthesized and purified by HPLC (Biomedical Genomics Center, University of Minnesota, Minneapolis, MN).

\section{Behavioral testing of the effects of VGF peptides}

VGF peptides were administered intrathecally in conscious adult male mice (20-25 g) as described (Hylden and Wilcox, 1981). A 30-gauge, 0.5 -inch needle connected to a $50 \mu \mathrm{l}$ Luer-hub Hamilton syringe was used to deliver $5 \mu \mathrm{l}$ of saline (vehicle), AQEE-30, LQEQ-19, or AQEE-11. Baseline tail-flick (TF) latency data in response to water immersion $\left(49^{\circ} \mathrm{C}\right)$ was collected on all mice before the injection and at selected time points after injection. In some cases, LQEQ-19- and saline-injected mice were killed by perfusion fixation immediately after behavioral testing. TF latency data was analyzed by first calculating delta TF values (Experimental TF latency - Baseline TF latency) and using those values in the formula for percentage inhibition for the mean of each dose group [(Control delta TF latency - Experimental delta TF latency)/(Control delta $\mathrm{TF}$ latency) $\times 100$ ]. In some experiments, the following inhibitors were administered as a $5 \mathrm{~min}$ pretreatment: 7-NI (7-nitroindazole), $10 \mathrm{nmol}$ (Tocris Biosciences); L-NAME ( $N$ - $\omega$-nitro-L-arginine methyl ester), $100 \mathrm{nmol}$ (Sigma-Aldrich); MK801 [(+)-5-methyl-10,11-dihydro$5 H$-dibenzo [a,d] cyclohepten-5,10-imine maleate], $10 \mathrm{nmol}$ (Sigma-Aldrich); GF109203X (2-[1-(3-dimethylaminopropyl)-1 H-indol-3-yl]-3-
(1 H-indol-3-yl)maleimide), 1 and $10 \mathrm{nmol}$ (Tocris Biosciences); KT5720 [(9S,10R,12R)-2,3,9,10,11,12-hexahydro-10-hydroxy-9-methyl-1-oxo9,12-epoxy- $1 \mathrm{H}$-diindolo[1,2,3-fg:3',2',1'-kl] pyrrolo[3,4-i] [1,6]benzodiazocine-10-carboxylicacid hexyl ester], $1.7 \mathrm{nmol}$ (Sigma-Aldrich); U0126 [1,4-diamino-2,3-dicyano-1,4-bis( $o$-aminophenylmercapto)butadiene], $2.5 \mathrm{nmol}$ (Tocris Biosciences); SB202190 [4-(4-fluorophenyl)-2(4-hydroxyphenyl)-5-(4-pyridyl) $1 \mathrm{H}$-imidazole], $0.1,1$, and $2.5 \mathrm{nmol}$ (Tocris Biosciences); and SB600125, $2.5 \mathrm{nmol}$ (Tocris Biosciences). The selected doses were similar to doses used previously in similar experimental paradigms (Inoue and Ueda, 2000; Sakurada et al., 2002; Wu et al., 2006; Gabra et al., 2007; Komatsu et al., 2007). 7-NI, L-NAME, MK801, GF109203X, and KT5720 were dissolved with 0.9\% normal saline, pH 7.2. U0126, SB202190, and SB600125 were dissolved in DMSO and diluted to a final concentration of $5 \%$ DMSO with $0.9 \%$ normal saline, $\mathrm{pH} 7.2$.

\section{Immunohistochemistry}

For preparation of DRG or spinal cord tissue sections, rats or mice were deeply anesthetized with isoflurane and perfused via the heart with calcium-free Tyrode's solution (in mM: $116 \mathrm{NaCl}, 5.4 \mathrm{KCl}, 1.6$ $\mathrm{MgCl}_{2} \cdot 6 \mathrm{H}_{2} 0,0.4 \mathrm{MgSO}_{4} \cdot 7 \mathrm{H}_{2} \mathrm{O}, 1.4 \mathrm{NaH}_{2} \mathrm{PO}_{4}, 5.6$ glucose, and 26 $\mathrm{Na}_{2} \mathrm{HCO}_{3}$ ), followed by fixative (described above), and finally with $10 \%$ sucrose in PBS. DRG and spinal cords were removed and incubated in $10 \%$ sucrose overnight at $4^{\circ} \mathrm{C}$. Tissues were cryostat sectioned $(14 \mu \mathrm{m})$ and thaw mounted onto gelatin-coated slides. Coverslips with cultured cells or tissue sections were preabsorbed in blocking buffer (PBS containing $0.3 \%$ Triton X-100, $1 \%$ BSA, and $1 \%$ 
normal donkey serum) for $30 \mathrm{~min}$, incubated in primary antisera listed below (coverslips for $4 \mathrm{~h}$ at room temperature; tissue sections overnight at $4^{\circ} \mathrm{C}$ ), rinsed with $\mathrm{PBS}$ three times for $10 \mathrm{~min}$, incubated in cyanine 3 -conjugated or cyanine 2-conjugated secondary antisera (1:300 and 1:100, respectively; Jackson ImmunoResearch) for $1 \mathrm{~h}$ at room temperature, washed with PBS, and mounted onto slides or coverslipped using PBS/glycerol containing $0.1 \%$ p-phenylenediamine (Sigma). In some cases, DRG sections were counterstained with YOYO-1 (Invitrogen) before coverslipping.

Primary antisera for immunohistochemistry VGF antisera. At the onset of the immunohistochemical experiments, several commercial VGF antisera (Santa Cruz Biotechnology) were evaluated for their ability to label cultured DRG neurons. Adequate labeling in the neuronal cell bodies was obtained with the N-terminal antiserum anti-VGF (D-20) diluted at 1:300. This antiserum was used for quantitative image analysis in DRG cultures and DRG tissue sections (see below). Subsequently, it was noted that this antiserum did not label the processes of cultured neurons and that the labeling in superficial dorsal horn of spinal cord sections was very weak. Therefore, we generated antisera to the VGF C terminus using previously described methods (Vulchanova et al., 1997). Briefly, the peptide AQEE-30 was conjugated to bovine thyroglobulin (Sigma) using glutaraldehyde. The peptide conjugate $(1 \mathrm{mg} / \mathrm{ml})$ was emulsified with an equal volume of Freund's adjuvant (Difco) and injected into female guinea pigs $(n=4$; Harlan $)$ at 2 week intervals $(0.5 \mathrm{mg}$ of peptide for initial and $0.25 \mathrm{mg}$ of peptide for subsequent immunizations). Staining with anti-VGF antisera was blocked by preabsorption of the antisera with the cognate peptide $(10 \mu \mathrm{g} / \mathrm{ml})$. In addition, the specificity of the antisera was ascertained by Western blot analysis, which showed bands consistent with previous reports (Fig. 1), as well as by double labeling with the N-terminal antisera in DRG, which showed an overlapping pattern of staining (data not shown). The C-terminal VGF antisera (1:1000) were used for quantitative image analysis in spinal cord. Additionally, the quantification in DRG cultures was repeated with the C-terminal antisera, yielding the same results as the $\mathrm{N}$-terminal antisera.

Other primary antisera. The following other primary antisera were used for immunohistochemistry: mouse anti-protein gene product (PGP) (1:1000; Biogenesis); rabbit anti-TrkA (1:1000; Advanced Targeting Systems); guinea pig anti-P2X ${ }_{3}$ (1:500) (Vulchanova et al., 1997); goat anti-ATF3 (1:300; Santa Cruz Biotechnology); rabbit anti-calcitonin gene-related peptide (CGRP) (1:1000; ImmunoStar); rabbit antiphosphorylated (phospho)-p38 (1:100; Cell Signaling Technology); mouse anti-neuronal-specific nuclear protein (NeuN) (1:1000; Millipore Bioscience Research Reagents); mouse anti-GFAP (1:1000; Cell Signaling Technology); rat anti-CD68 (1:100; AbD Serotec).

\section{Quantitative image analysis}

During image analysis, the observer was blinded to the experimental treatments.

Cultured DRG neurons. Nine coverslips from three different DRG cultures (three coverslips per culture) were analyzed for each time point.
Naive

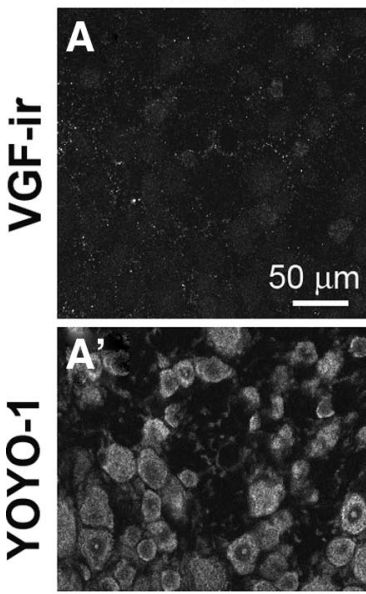

D
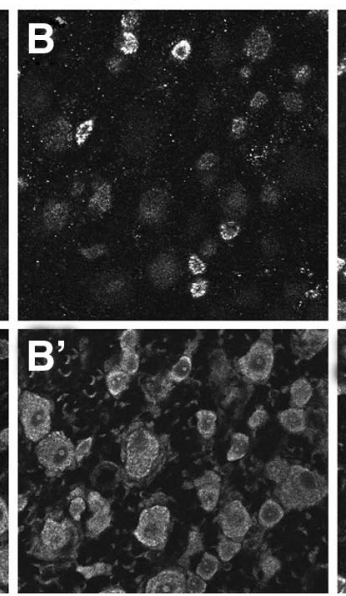
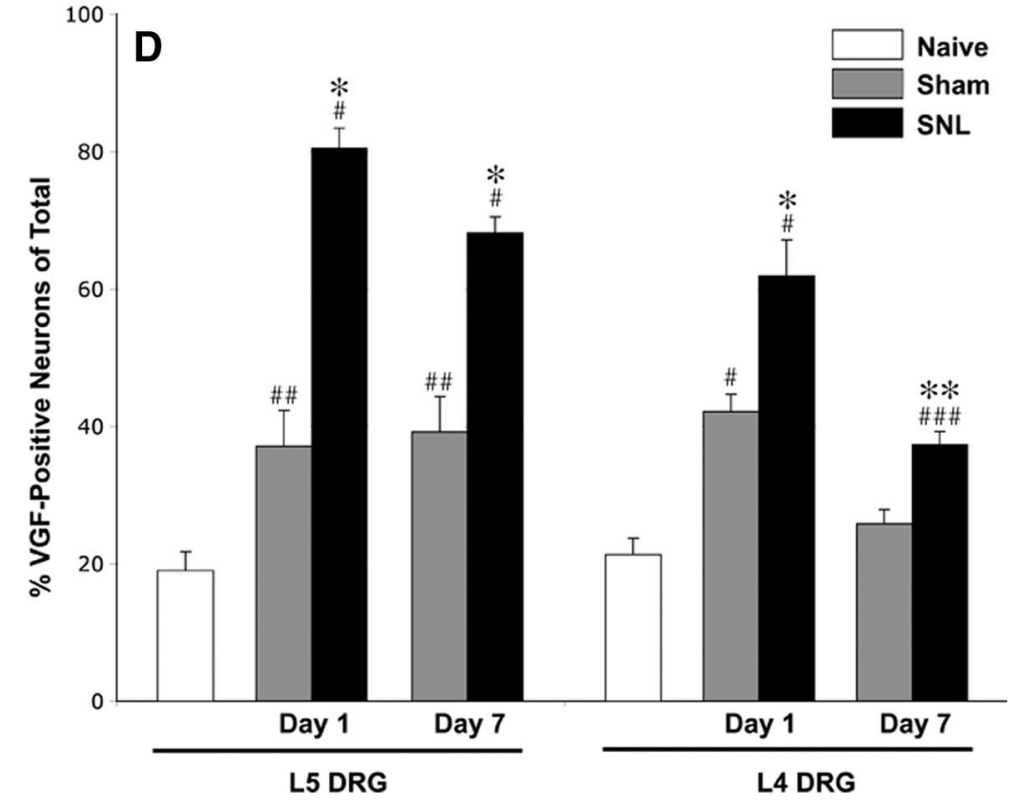

SNL

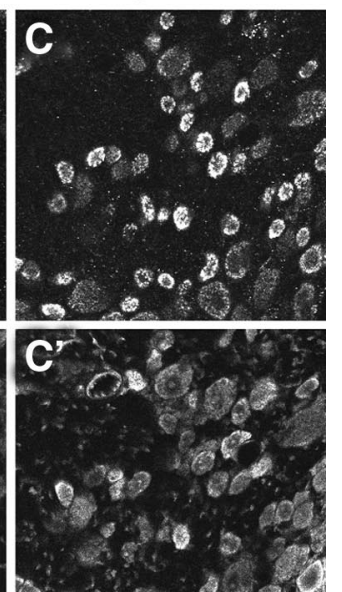

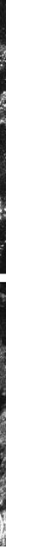

Figure 2. Nerve injury-induced upregulation of VGF in DRG neurons. $\boldsymbol{A}-\boldsymbol{C}$, VGF-IR increased dramatically $1 \mathrm{~d}$ after SNL (C) and a lesser extent after sham surgery $(\boldsymbol{B})$. Corresponding images of YOY0-1 labeling $\left(\boldsymbol{A}^{\prime}-\boldsymbol{C}^{\prime}\right)$ show all cells in the fields of view th injured L5 and uninjured L4 DRG. Sham surgery resulted in a more moderate but significant increase in the number of VF-positive neurons in L5 DRG at day 1 and day 7 and in L4 DRG at day 1. Significant changes are indicated by * when compared with sham and \# when compared with naive $\left({ }^{*} p<0.001 ;{ }^{* *} p<0.05 ;{ }^{\#} p<0.001 ;{ }^{\# \#} p<0.005 ;{ }^{\# \# \#} p<0.01\right.$; one-way ANOVA and Student-Newman-Keuls test for multiple comparisons; $n=4$ in each group).

Stacks of PGP9.5/VGF double-labeled confocal images (three per coverslip) collected with a Bio-Rad MRC-1024 microscope were analyzed using NIH ImageJ. Neurons, identified based on their PGP9.5 labeling, were outlined, and the average intensity of VGF immunoreactivity (IR) of each neuron was measured. For each of the three cultures, 18 VGF-negative cells (two per image) were identified from the $t_{0}$ images (negative cells were often hard to identify in $t_{24}$ images). The threshold intensity for identifying VGF-positive neurons for $t_{0}$ and $t_{24}$ of each culture was defined as the average intensity of these negative cells +2 SDs.

DRG neurons in tissue sections. For each DRG, five sections equally spaced throughout its length were triple labeled with anti-VGF $(\mathrm{N}$ terminal), YOYO-1, and either anti-TrkA or anti-P2 $\mathrm{X}_{3}$. Stacks of triplelabeled confocal images (nine per DRG) were analyzed using NIH ImageJ. Neurons were identified and outlined based on their Nissl-like YOYO-1 labeling, and cell body area and the average intensity of VGF staining of each neuron was measured. Three VGF-negative neurons were identified in each image, and the threshold intensity for identifying 
VGF TrkA

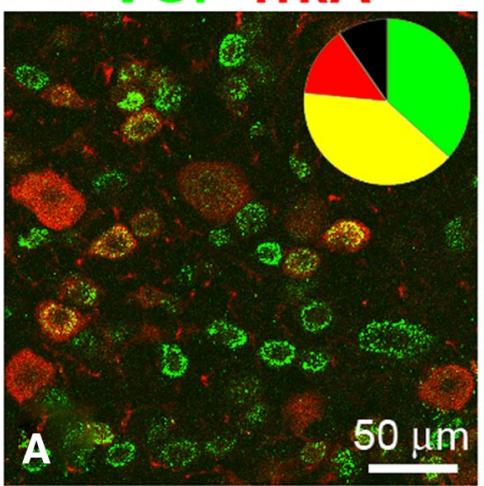

VGF P2X3

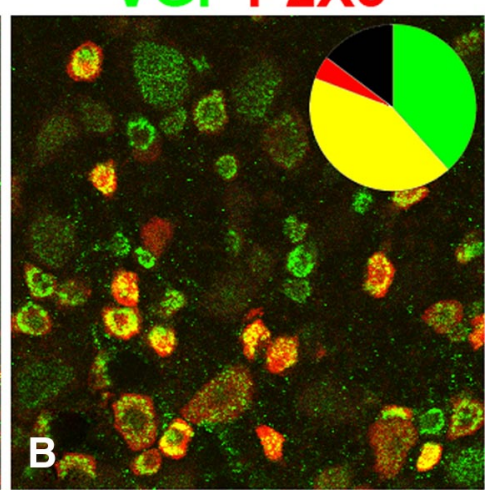

Figure 3. Colocalization of VGF-IR with TrkA-IR and P2X $X_{3}-I R$ in $L 5 D R G 1 \mathrm{~d}$ after SNL. The pie chart insets show the proportions of single-labeled VGF-positive cells (green), single-labeled TrkA-positive ( $\boldsymbol{A}$, red) or P2X $\mathrm{X}_{3}$-positive ( $\boldsymbol{B}$, red) cells, and double-labeled cells (yellow). $\boldsymbol{A}$, Colocalization of VGF-IR and TrkA-IR. The proportion of double-labeled cells (yellow) represents $51.9 \pm 1.4 \%$ of the VGF-positive neurons (green + yellow) and $70.7 \pm 3.5 \%$ of the TrkA-positive neurons (red + yellow). B, Colocalization of VGF-IR and P2X3-IR. The proportion of double-labeled cells (yellow) represents $52.3 \pm 3.6 \%$ of the VGF-positive neurons (green + yellow) and $90.8 \pm 2.3 \%$ of the TrkA-positive neurons (red + yellow).

Table 2. Size distribution of VGF-positive neurons after SNL

\begin{tabular}{lllll}
\hline & $\begin{array}{l}\text { Small/medium } \\
\text { (diameter }<25 \mu \mathrm{m}), \\
\text { \% of total }\end{array}$ & $\begin{array}{l}\mathrm{VGF}^{+} \text {neurons, } \\
\text { \% of small/ } \\
\text { medium }\end{array}$ & $\begin{array}{l}\text { Large (diameter } \\
>25 \mu \mathrm{m}),\end{array}$ & $\begin{array}{l}\text { V of total } \\
\text { \% of large }\end{array}$ \\
\hline L5 & & & & \\
Day 1 & $78.2 \pm 2.1$ & $86 \pm 1.6^{*}$ & $22.4 \pm 2.3$ & $59.8 \pm 5.8^{* * *}$ \\
Day 7 & $76.9 \pm 3.5$ & $64.6 \pm 3.3^{*}$ & $20.8 \pm 3.9$ & $75.8 \pm 3.1^{* * *}$ \\
L4 & & & & \\
Day 1 & $65.9 \pm 1.8$ & $65.1 \pm 5.9^{* *}$ & $34.7 \pm 1.5$ & $40.8 \pm 3.3$ \\
Day 7 & $65.8 \pm 3.7$ & $40.3 \pm 3.9^{* *}$ & $36.5 \pm 4.6$ & $30.2 \pm 7$ \\
\hline
\end{tabular}

The percentage of small/medium and large VGF-positive neurons in L5 and L4 DRG was compared between day 1 and day 7. At day 7, there was a significant decrease in the number of small/medium VGF-positive neurons in both $\mathrm{L} 5\left({ }^{*} p<0.005, t\right.$ test) and $\mathrm{L} 4\left({ }^{*} p<0.05, t\right.$ test) DRG. The number of large VGF-positive neurons at day 7 was significantly increased (*** $p<0.05$, one-tailed $t$ test) in L5 DRG and decreased in L4 DRG.

VGF-positive neurons was defined as the average of the three unlabeled neurons +2 SDs. Similarly, the average intensity of TrkA and $\mathrm{P}_{2} \mathrm{X}_{3}$ staining was measured, and the threshold intensity for identifying positive neurons was determined based on the average intensity of three unlabeled neurons.

$V G F-I R$ and CGRP-IR in rat spinal cord. Quantitative analysis was performed at two levels of the L5 spinal segment that were separated by $\sim 1 \mathrm{~mm}$. The results from these two levels were similar. In sections double labeled for VGF and CGRP, confocal images of dorsal horn were analyzed using NIH ImageJ. For each spinal cord, a threshold intensity, corresponding to the average intensity of unlabeled regions within the dorsal horn, was selected to separate VGF labeling from background. The number of pixels with intensity above threshold (thresholded area) was measured in the superficial laminae of the right and left dorsal horn. To eliminate variability between animals attributable to tissue processing, labeling on the left side (operated in SNL and sham animals) was normalized to the right side. For each spinal cord, data were collected from three sections, averaged, and expressed as percentage change [i.e., (ipsilateral - contralateral)/contralateral $\times 100$ ]. CGRP-IR in dorsal horn was analyzed as described for VGF-IR.

phospho-p38-IR in mouse spinal cord. Dorsal horn images were collected with a confocal microscope (Olympus FluoView 1000 IX2). For each image, a threshold intensity, corresponding to the maximum intensity of an unlabeled region, was selected to separate phospho-p38 labeling from background. The pixel area of phospho-p38-IR above background was normalized to the spinal cord area included in the image and expressed as percentage thresholded area. For each animal, percentage thresholded area was determined by adding percentage thresholded area of both left and right dorsal horns from three spinal cord sections.

\section{Microglial cultures}

The BV-2 microglial cell line (a kind gift from Dr. Jonathan Godbout, The Ohio State University, Columbus, $\mathrm{OH}$ ) was maintained in DMEM supplemented with 10\% FBS. Cells were treated with LQEQ-19 or vehicle (serumfree DMEM) for 2 min. For Western blot, treated cells were lysed [ $20 \mathrm{~mm}$ Tris, $150 \mathrm{~mm}$ $\mathrm{NaCl}, \mathrm{pH} 8$, and $1 \%(\mathrm{v} / \mathrm{v})$ Triton X-100] in the presence of protease inhibitors (Complete Mini, EDTA-free; Roche,) and phosphatase inhibitors (Halt Phosphatase Inhibitor Cocktail; Thermo Fisher Scientific) on ice for $1 \mathrm{~h}$. The samples were centrifuged $\left(40,000 \times g, 4^{\circ} \mathrm{C}, 30\right.$ $\mathrm{min})$ and loaded ( $60 \mu \mathrm{g} /$ lane $)$ onto $4-12 \%$ BisTris gels (Invitrogen) and run at $130 \mathrm{~V}$ for 90 min. Next proteins were transferred to nitrocellulose membranes and treated as follows: (1) incubated in blocking buffer [Tris-buffered saline, $0.05 \%(\mathrm{v} / \mathrm{v})$ Tween $20,5 \%(\mathrm{w} / \mathrm{v})$ nonfat milk] for $120 \mathrm{~min}$ at room temperature; (2) washed with TBS containing Tween 20 (four times for $10 \mathrm{~min}$ ); (3) incubated in antiphospho-p38 (1:700; Cell Signaling Technology) in TBS containing $0.5 \%$ Tween 20 and $5 \%$ BSA at $4^{\circ} \mathrm{C}$ for $12 \mathrm{~h}$; (4) washed in TBS containing $0.5 \%$ Tween 20 (four times for $10 \mathrm{~min}$ ); (5) incubated in goat anti-rabbit-IRDye800CW antibody (Li-Cor Biotechnology) for $90 \mathrm{~min}$ at room temperature; (6) washed in TBS containing $0.5 \%$ Tween 20 (three times for $10 \mathrm{~min}$ ) and TBS (two times for $10 \mathrm{~min}$ ). The membrane was then scanned with the Li-Cor Biotechnology Odyssey imager. The fluorescence intensities of the phosphorylated p38 signals were measured, and the membrane was stripped by NewBlot Nitro Stripping Buffer (Li-Cor Biotechnology) for 4 min. Removal of antibodies was verified by rescanning of the membrane. The membrane was then reprobed as above except with rabbit anti-p38 as the primary antibody (1:1000, catalog \#2831; Cell Signaling Technology). The phospho-p38 intensities were normalized to their corresponding total p38 intensities and then normalized to the control treatment (0 nM LQEQ-19) values. For immunohistochemistry, cells were grown to confluence on coverslips and, after treatment, were processed as described above for DRG cultures.

\section{Results}

\section{Proteomic analysis of cultured sensory neurons}

We postulated that, over the first $24 \mathrm{~h}$ after dissociation and plating, cultured adult sensory neurons undergo changes in protein expression that are similar to those occurring in axotomized neurons. Cytoplasmic and nuclear fractions obtained from DRG cultures at $t_{0}$ and $t_{24}$ were compared using iTRAQ-based quantification of relative abundance combined with 2D LC-MS/MS. A database search using spectra detected by 2D LC-MS/MS identified 3569 distinct peptides. These peptides were mapped to 537 proteins ( $\geq 66 \%$ confidence), of which 481 were identified with $>95 \%$ confidence. Quantification of protein ratios in the four samples was based on the ratios of the iTRAQ reporter tags for each identified peptide (supplemental Fig. 1, available at www. jneurosci.org as supplemental material). The data were further examined using IPA. Of the 537 identified proteins, 436 were annotated in the IPA Knowledge Base. The majority of these proteins $(\sim 80 \%)$ were annotated as cytoplasmic, and only $16 \%$ were annotated as nuclear. A large number of cytoplasmic proteins was detected in the nuclear fractions, preventing adequate evaluation of changes in nuclear proteins. Therefore, subsequent analysis was focused on changes in protein levels in the cytoplasmic fractions.

The ratio cytoplasmic $t_{24} /$ cytoplasmic $t_{0}$ indicated that the majority of quantified proteins $(\sim 60 \%)$ were changed $<1.5$-fold between $t_{0}$ and $t_{24}$, indicating consistency of sample preparation 
at the two time points. The proteins that were increased more than twofold after $24 \mathrm{~h}$ in culture are shown in Table 1 . The potential functional relevance of these proteins was inferred by an IPA network analysis-guided literature review. However, confirmation of upregulation and analysis of actual functional relevance requires validation by molecular and cellular biology methods. We focused on elucidating the role of VGF, which demonstrated the largest change in expression. The neurosecretory protein VGF was identified by a single peptide, and iTRAQ relative quantification showed a 45 -fold increase in the levels of this peptide at $t_{24}$, suggesting upregulation of VGF in the DRG cultures (supplemental Fig. 1, available at www.jneurosci.org as supplemental material).

\section{VGF is upregulated in cultured sensory neurons}

The increase in VGF levels in cultured DRG neurons at $t_{24}$ was confirmed by Western blot analysis and immunocytochemistry (Fig. 1). Two protein bands, one of $\sim 90 \mathrm{kDa}$ and one of $\sim 70 \mathrm{kDa}$ were seen in homogenates from cells maintained in culture for $24 \mathrm{~h}$ but not in homogenates from cells that were harvested shortly after plating. Immunocytochemical analysis of the cultures indicated that the number of VGF-positive neurons, expressed as the percentage of neurons identified by the pan-neuronal marker PGP 9.5 , was significantly increased at $t_{24}$ compared with $t_{0}\left(20 \pm 4 \%\right.$ at $t_{0}$ compared with $82 \pm 7 \%$ at $t_{24} ; p<0.05, t$ test $)$. The quantification of the percentage of VGF-positive neurons was not confounded by a change in the total number of neurons over the $24 \mathrm{~h}$ period because the total number of PGP-positive cells at $t_{0}$ and $t_{24}$ (91 \pm 7 and $86 \pm 15$, respectively) was not significantly different. Similar immunocytochemical results were obtained with the C-terminal VGF antiserum and the commercially available $\mathrm{N}$-terminal antiserum.

\section{VGF is upregulated in DRG after nerve injury}

We predicted that changes in protein expression in cultured neurons would parallel nerve injury-induced changes in the L5 SNL model. Therefore, the expression of VGF was examined immunohistochemically in L5 DRG $24 \mathrm{~h}$ after SNL. As shown in Figure 2 , the number of VGF-positive neurons in L5 DRG of SNL animals was significantly increased compared with sham-operated and naive animals. One day after SNL, 80\% of L5 DRG neurons were VGF positive compared with $37 \%$ in sham-operated animals and 20\% in naive animals. Analysis of colocalization showed overlap of VGF-IR with both TrkA and P2X 3 labeling (Fig. 3). Of the VGF-positive neurons, $51.9 \pm 1.4 \%$ were TrkA positive and $52.3 \pm 3.6 \%$ were $\mathrm{P}_{2} \mathrm{X}_{3}$ positive; conversely, $90.8 \pm 2.3 \%$ of the $\mathrm{P}_{2} \mathrm{X}_{3}$-positive and $70.7 \pm 3.5 \%$ of the TrkA-positive neurons in the injured L5 DRG were also VGF positive. Size distribution analysis indicated that the subset of VGF-positive cells in injured
VGF-ir
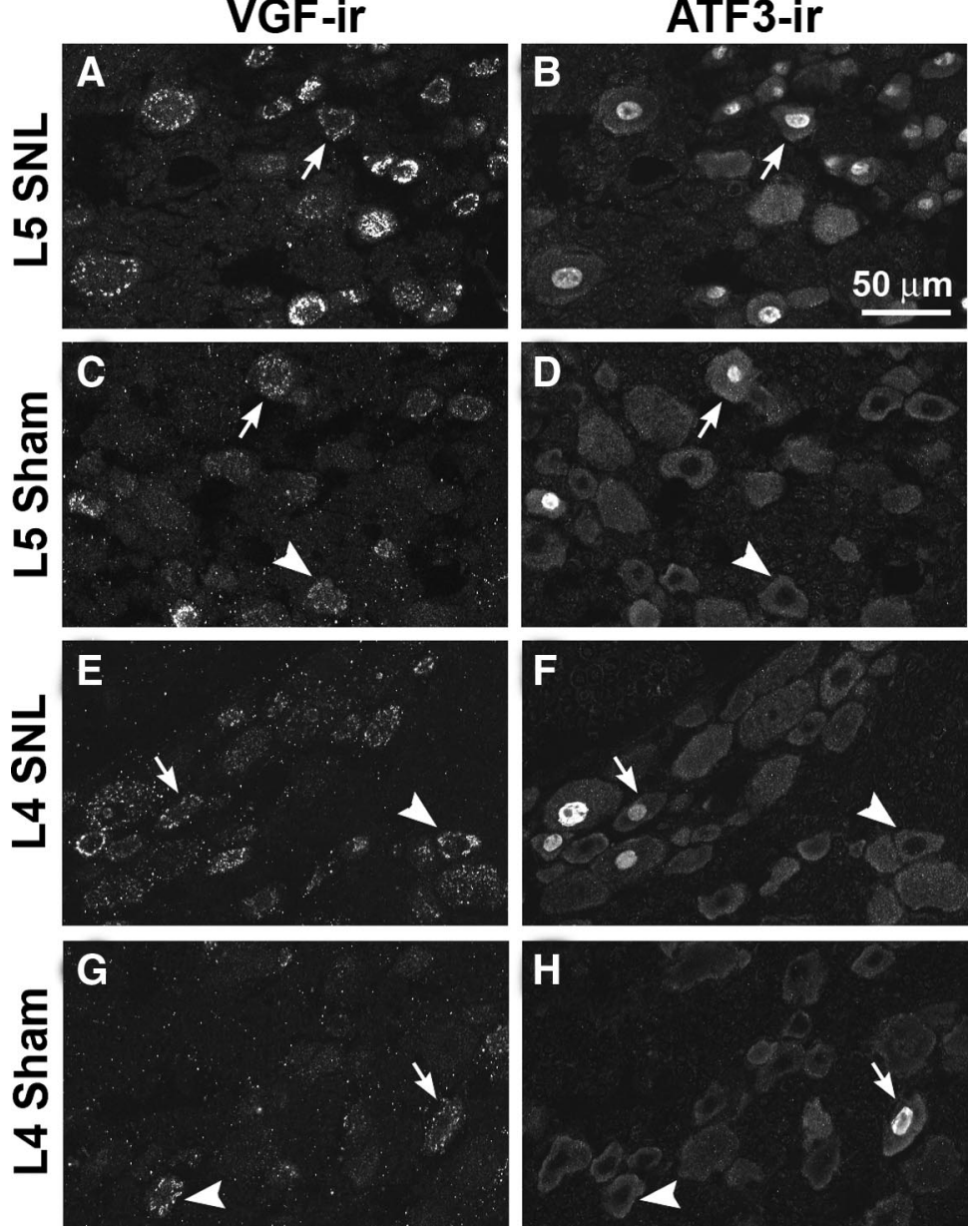

Figure 4. Relationship of VGF- and ATF3-IR in L5 and L4 DRG $1 \mathrm{~d}$ after SNL or sham surgery. In double-labeled sections, VGF- and ATF3-IR overlapped substantially in injured L5 DRG $(\boldsymbol{A}, \boldsymbol{B})$. In sham L5 DRG $(\boldsymbol{C}, \boldsymbol{D})$, in L4 DRG from SNL animals $(\boldsymbol{E}, \boldsymbol{F})$, and in sham L4DRG $(\boldsymbol{G}, \boldsymbol{H})$, VGF-IR was present in ATF3-positive and ATF3-negative neurons. Arrows show examples of colocalization of VGF-IR and ATF3-IR. Arrowheads show examples of VGF-positive neurons without ATF3-IR in their nuclei.

L5 DRG included small/medium-sized and large (diameter $>25$ $\mu \mathrm{m}$ ) neurons (Table 2). The significant increase in VGF-IR was maintained $7 \mathrm{~d}$ after SNL. Notably, whereas the number of small/ medium-sized VGF-positive neurons at that time was decreased relative to day 1 , the number of large VGF-positive neurons was slightly increased (Table 2).

In addition to the injured L5 DRG neurons, VGF was upregulated in uninjured L4 DRG neurons after SNL (Fig. 2D). The number of VGF-positive cells was significantly increased in L4 DRG both 1 and $7 \mathrm{~d}$ after SNL compared with sham controls and naive animals. Similar to L5 DRG, at day 1, approximately half $(53.3 \pm 4.4 \%)$ of the VGF-positive neurons were also TrkA positive (supplemental Table 1, available at www.jneurosci.org as supplemental material).

It was possible that, in L4 DRG of SNL animals and DRG of sham-operated animals, the VGF upregulation was restricted to neurons inadvertently injured during the surgery. To address this possibility, we examined immunohistochemically the colocalization of VGF and the nerve injury-inducible transcription factor ATF3 (Fig. 4). As described previously (Shortland et al., 2006), we found that ATF3-IR was present in virtually all L5 neurons of SNL animals as well as in a limited number of neurons within L4 and sham DRG. In the injured L5 neurons, we observed a nearly complete overlap of VGF-IR and ATF3-IR. However, in L4 DRG 

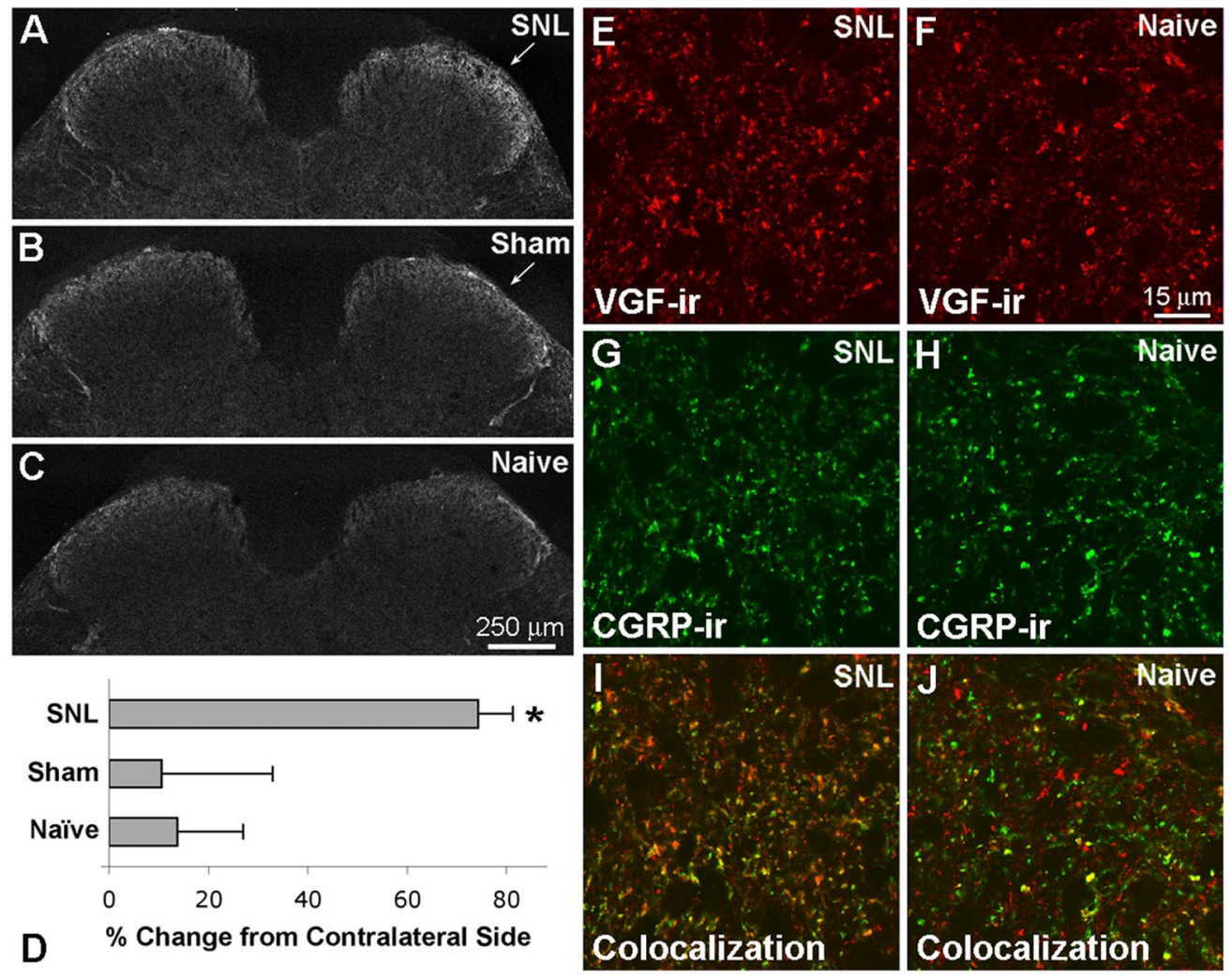

Figure 5. Changes in VGF-IR in L5 segment of spinal cord after SNL. $A-C$, Three days after SNL, VGF-IR appeared increased within the dorsal horn ipsilateral to SNL $(\boldsymbol{A})$ compared with sham surgery $(\boldsymbol{B})$ and naive animals (C). D, Quantitative analysis indicated a significant increase in VGF-IR ipsilateral to SNL compared with sham surgery and naive spinal cord (one-way ANOVA and StudentNewman-Keuls multiple comparisons test, $p<0.05 ; n=4$ for each group). $\boldsymbol{E}-\boldsymbol{J}$, Compared with naive spinal cord $(\boldsymbol{F}, \boldsymbol{H}, \boldsymbol{J}), \mathrm{VGF}-\mathrm{IR}$ (red) was increased after SNL ( $\boldsymbol{E}, \boldsymbol{G}, \boldsymbol{I})$, whereas $(\mathrm{GRP}-\mathrm{IR}$ (green) appeared unchanged at this time point. The colocalization of VGF- and CGRP-IR in superficial dorsal horn was also increased after SNL as indicated by the presence of more yellow and orange puncta ipsilateral to SNL (I) compared with naive spinal cord $(J)$.

of SNL animals, there were many VGF-positive cells that were ATF3 negative. Similarly, in sham DRG, VGF-IR was not restricted to ATF3-IR neurons. These results show that VGF was upregulated in injured as well as uninjured neurons.

\section{VGF is upregulated in spinal cord after nerve injury}

VGF-IR also increased in the superficial dorsal horn of the spinal cord after SNL. VGF immunofluorescence was measured in the superficial dorsal horn of three sections of L5 spinal cord from four different animals $3 \mathrm{~d}$ after SNL surgery. VGF-IR was significantly increased within the dorsal horn ipsilateral to SNL compared with sham surgery and naive animals (Fig. 5). In the same sections, there was no difference in CGRP-IR in the three experimental groups (data not shown). To determine whether VGF-IR increased in central terminals of primary afferent neurons or in intrinsic spinal cord neurons, we examined the relationship of VGF-IR to CGRP-IR, which in dorsal horn is localized exclusively in primary afferent terminals. The colocalization of VGF-IR and CGRP-IR in the superficial dorsal horn ipsilateral to SNL was increased compared with spinal cord from naive animals, consistent with elevation in VGF levels in central terminals of primary afferent neurons after SNL (Fig. $5 E-J$ ). It should be noted that the abundance of VGF-IR in spinal cord as revealed in these experiments by our C-terminal antiserum may be underestimated if differential proteolytic processing of VGF (Brancia et al., 2005) results in fragments that are not recognized by this antiserum.

\section{VGF is upregulated after CFA-induced inflammation}

The increased number of VGF-IR neurons in DRG from sham animals suggested that VGF might also be induced in inflam- matory conditions because the sham surgery is accompanied by substantial tissue damage and inflammation. Therefore, we examined changes in VGF-IR $24 \mathrm{~h}$ after CFA-induced hindpaw inflammation. CFA inflammation resulted in a more modest but still significant increase in the number of VGF-expressing neurons in L5 DRG $(28.2 \pm 0.3 \%$ in CFA L5 DRG compared with $19.0 \pm 2.8 \%$ in naive L5 DRG; $p<0.05, t$ test). In L5 DRG from CFA-treated animals, $65.5 \pm 5.2 \%$ of the VGF-positive neurons were also TrkA positive (supplemental Table 1, available at www. jneurosci.org as supplemental material). Thus, VGF expression in sensory neurons appears to be induced by a spectrum of manipulations that includes varying degrees of inflammation and nerve injury.

\section{VGF-derived peptides evoke thermal hyperalgesia}

Previous studies have reported biological activity of the VGF C-terminal peptides TLQP-62, AQEE-30, and LQEQ-19 (Alder et al., 2003; Succu et al., 2005). To determine whether they have a role in nociceptive processing, AQEE-30 and LQEQ-19 were injected intrathecally into naive adult mice (Fig. 6). In the warmwater $\left(49^{\circ} \mathrm{C}\right)$ tail-immersion assay, mice show baseline tail-flick latencies in the range of $6-9 \mathrm{~s}(x=7.77 \pm 0.06 \mathrm{~s}$, mean \pm SEM, $n=156$, for data shown in Figs. 6, 7). After intrathecal delivery, AQEE-30 evoked a partial thermal hyperalgesia by $10 \mathrm{~min}$, which was fully expressed by $30 \mathrm{~min}$ and persisted for at least $60 \mathrm{~min}$ and up to $90 \mathrm{~min}$ at the highest dose (Fig. 6, Table 3). The induction of thermal hyperalgesia was dose dependent, as evidenced by a significant difference in the magnitude of the hyperalgesia evoked by the different doses at the 30 min time point (one-way ANOVA, $F_{(3,20)}=3.48 ; p<0.05$, Tukey's post hoc test). However, there was 

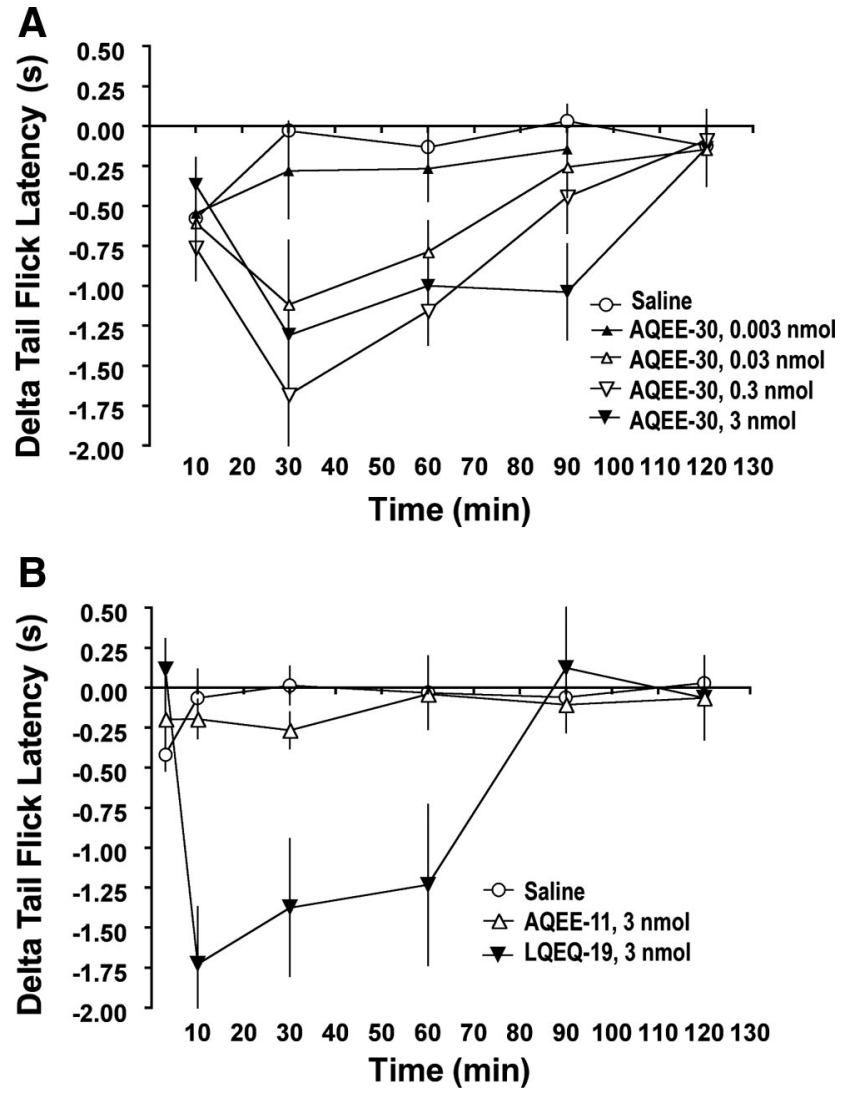

Figure 6. VGF-derived peptides evoke thermal hyperalgesia. $\boldsymbol{A}$, Intrathecal injection of AQEE-30 dose dependently evoked thermal hyperalgesia in mice as detected by the warmwater $\left(49^{\circ} \mathrm{C}\right)$ tail-immersion assay. The hyperalgesia persisted for up to $60 \mathrm{~min}(0.03,0.3$, and 3 $\mathrm{nmol})$ and $90 \mathrm{~min}$ at the highest dose $(3 \mathrm{nmol})$. Data are expressed as the reduction in withdrawal latency compared with baseline for each individual mouse (delta). $\boldsymbol{B}$, Thermal hyperalgesia was evoked by intrathecal injection of LQEQ-19, which corresponds to the C-terminal 19 aa of AQEE-30, but not by AQEE-11, which corresponds to the leading 11 aa of AQEE-30. AQEE-11 and LQEQ-19 were tested at a dose ( $3 \mathrm{nmol}$ ) equimolar to the highest dose of AQEE-30.

no statistical difference between the magnitudes of the thermal hyperalgesia evoked by the two highest doses $(3 \mathrm{nmol},-1.3 \pm$ $0.19 \mathrm{~s} ; 0.3 \mathrm{nmol},-1.7 \pm 0.34 \mathrm{~s} ; p>0.05 ; n=6)$.

LQEQ-19, which corresponds to the last 19 aa of AQEE-30, evoked hyperalgesia of similar magnitude $(-1.4 \pm 0.43 ; n=6)$ but with a more rapid onset to full expression and a shorter duration. In contrast, AQEE-11, which corresponds to the leading 11 aa of AQEE-30, had no effect on tail-withdrawal latency (Fig. 6, Table 3).

\section{VGF-derived peptides activate $\mathrm{p} 38$ MAPK in microglia}

Several pharmacological agents known to interfere with pathways involved in pain processing were evaluated for inhibition of the thermal hyperalgesia evoked by AQEE-30 and LQEQ-19. These included inhibitors of nitric oxide synthase (7-NI, 10 nmol; L-NAME, $100 \mathrm{nmol})$, NMDA receptor (MK801, $10 \mathrm{nmol}$ ), protein kinase C (GF109203X, 1 and $10 \mathrm{nmol})$, protein kinase A (KT5720, $1.7 \mathrm{nmol}$ ), and MAPK (U0126, $2.5 \mathrm{nmol}$; SB202190, $0.1,1$, and $2.5 \mathrm{nmol}$; SB600125, $2.5 \mathrm{nmol}$ ). Inhibition of the spinal effects of the VGF peptides was achieved only by the p38 inhibitor SB202190, which dose dependently reversed AQEE-30 $(0.3 \mathrm{nmol})$ and LQEQ-19 (1 nmol) evoked thermal hyperalgesia (Fig. 7). The thermal hyperalgesia evoked by these doses was equivalent between the two peptides (AQEE-30, $-2.4 \pm 0.23 \mathrm{~s}$; LQEQ-19, $-2.3 \pm 0.37 \mathrm{~s} ; p>0.05$, Student's $t$ test; $n=6$ per

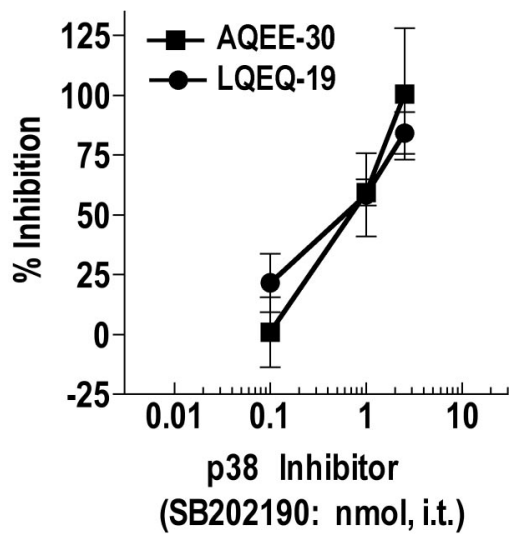

Figure 7. The p38 MAPK inhibitor SB202190 dose dependently reversed AQEE-30 and LQEQ-19 evoked thermal hyperalgesia. The inhibitor was injected intrathecally as a 5 min pretreatment before injection of equieffective doses of AQEE-30 $(0.3 \mathrm{nmol})$ or LQEQ-19 $(1 \mathrm{nmol})$. Thermal hyperalgesia was measured 30 and 10 min after intrathecal injection of AQEE- 30 and LQEQ-19, respectively. Data are expressed as percentage inhibition of the maximum thermal hyperalgesia (AQEE-30, $-2.29 \mathrm{~s}$; LQEQ-19, $-2.43 \mathrm{~s}$ ) detected in a separate control group pretreated with saline.

Table 3. Impact of high intrathecal dose of peptide on tail-flick latencies (TFL)

\begin{tabular}{|c|c|c|c|c|c|c|}
\hline Peptide & $n$ & Dose (i.t.) & Baseline TFL (s) & $10 \mathrm{~min}$ & $30 \mathrm{~min}$ & $90 \mathrm{~min}$ \\
\hline AQEE-30 & 6 & $3 \mathrm{nmol}$ & $7.5 s \pm 0.27$ & $7.2 s \pm 0.15^{*}$ & $6.2 s \pm 0.23^{* *}$ & $6.5 s \pm 0.48^{* *}$ \\
\hline LQEQ-19 & 6 & $3 \mathrm{nmol}$ & $7.4 s \pm 0.47$ & $5.7 \mathrm{~s} \pm 0.13^{* *}$ & $6.0 s \pm 0.67^{* *}$ & $7.5 s \pm 0.39$ \\
\hline AQEE-11 & 6 & $3 \mathrm{nmol}$ & $7.7 s \pm 0.33$ & $7.5 s \pm 0.31$ & $7.7 s \pm 0.35$ & $7.6 s \pm 0.36$ \\
\hline
\end{tabular}

${ }^{*} p<0.05$, significant difference from baseline. ${ }^{*} p<0.01$, significant difference from baseline.

group) and was not statistically different from the thermal hyperalgesia evoked in the previous experiment (Fig. 7) with the same doses and time points (Student's $t$ test, $p>0.05$ ). Administration of SB202190 alone had no effect on thermal withdrawal latencies.

Activation of p38 MAPK was examined immunohistochemically in spinal cords obtained at the time of peak hyperalgesia (10 min) from mice injected intrathecally with LQEQ-19 or saline (Fig. 8). In spinal cords from LQEQ-19-injected mice, we observed a nearly threefold increase in immunofluorescence for phosphorylated p38, measured as pixel area with staining intensity above background (percentage thresholded area, $0.36 \pm 0.08$ in LQEQ-19-treated compared with $0.13 \pm 0.04$ in saline-treated animals; $p<0.05$, one-tailed $t$ test; $n=3$ for each group) (Fig. $8 A-C)$. Immunoreactivity for phosphorylated p38 did not overlap with labeling for the neuronal marker NeuN and the astrocyte marker GFAP. However, it colocalized extensively with labeling for CD68, a marker for reactive microglia, suggesting that phosphorylated p38 was localized in spinal cord microglia (Fig. $8 D-G$ ). To determine whether LQEQ-19 has direct effects on microglia, we exposed the BV-2 microglial cell line to the peptide. This treatment resulted in the concentration-dependent increase of $\mathrm{p} 38$ phosphorylation in the cells (Fig. 9).

\section{Discussion}

The present study contributes to the characterization of a novel signaling system within spinal cord pain pathways. The potential relevance of VGF was first inferred from proteomic differential expression analysis of an in vitro model of injured sensory neurons. Subsequent experiments provided evidence for upregulation of VGF after nerve injury and inflammation and for the functional relevance of VGF peptides to spinal nociceptive processing. 

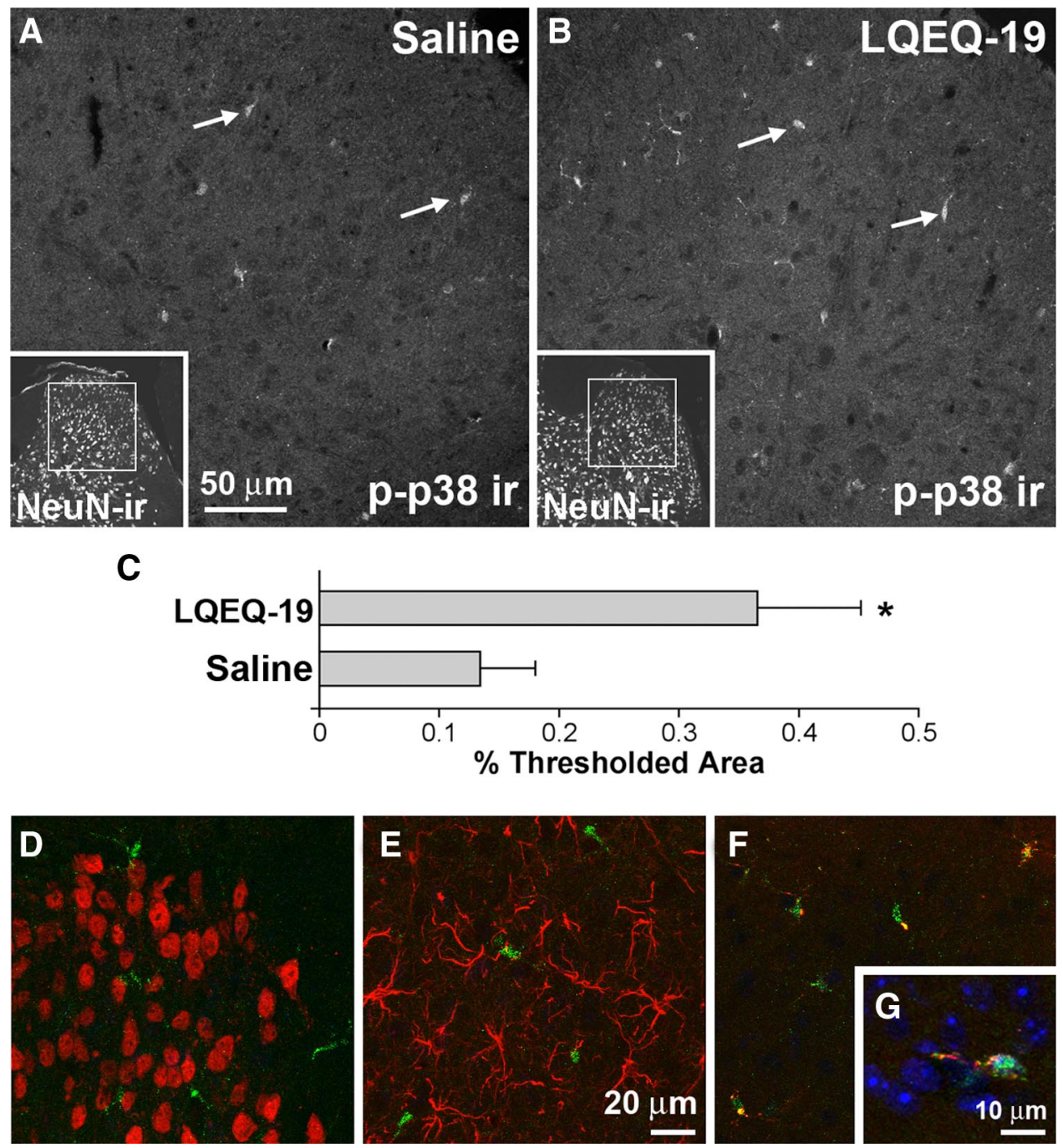

Figure 8. Increased phosphorylation of p38 MAPK in spinal microglia after intrathecal injection of LQEQ-19.A, B, Phospho-p38 (p-p38) immunofluorescence was increased 10 min after LQEQ-19 injection ( $3 \mathrm{nmol})$ compared with saline injection. Arrows show examples of phospho-p38-positive spinal microglia. Insets show NeuN staining of the same sections at lower magnification and indicate the approximate location of the high-magnification images within the dorsal horn. C, Quantitative image analysis of phospho-p38 immunofluorescence (percentage thresholded area, $0.36 \pm 0.08$ in LQEQ-19-treated compared with $0.13 \pm 0.04$ in saline-treated animals; $p<0.05$, one-tailed $t$ test; $n=3$ for each group). $D-F$, Double labeling of spinal cord sections from LQEQ- 19 injected mice for phospho-p38 ( $(\boldsymbol{E}$, green) and $\operatorname{NeuN}(\boldsymbol{C}$, red), GFAP (D, red), and $\operatorname{CD68}(\boldsymbol{E}$, red). Colocalization, appearing as yellow puncta in $\boldsymbol{E}$, was seen only with anti-phospho-p38 and anti-CD68. G, A cell labeled for phospho-p38 (green), CD68 (red), and the nuclear stain DAPI (4',6'-diamidino-2-phenylindole) (blue). Labeling for phospho-p38 is seen in the nucleus of the cell as well as in the cytoplasm, in which it overlaps with anti-CD68 staining.

\section{Proteomic analysis}

Large-scale expression analysis has been used to study global changes under conditions of chronic pain, leading to identification of genes with uncharacterized functions in pain signaling (Costigan et al., 2002; Wang et al., 2002; Valder et al., 2003; Komori et al., 2007). We used a proteomic approach to analyze early changes in protein levels within cultured DRG neurons, which were used as a model of axotomized neurons. Several of the proteins that were increased more than twofold are associated with oxidative stress, consistent with the hypoxia accompanying preparation of primary cultures. The transcription regulators APEX1 and YBX1 have also been linked to protection from oxidative stress (Kohno et al., 2003; Vasko et al., 2005; Qu et al., 2007). Moreover, IPA network analysis showed that APEX1, YBX1, and prothymosin $\alpha$ are regulated by casein kinase II, suggesting that the upregulation of these proteins may reflect activation of a common network that involves this enzyme. Another group of upregulated proteins is associated with membrane- cytoskeletal signaling at growth cones and presynaptic terminals and possibly with regulation of second-messenger availability (Laux et al., 2000; Diviani and Scott, 2001; Sundaram et al., 2004). For example, MARCKSL1 and BASP1/CAP-23 may control the phosphoinositol- $(4,5)$ biphosphate-dependent regulation of channels contributing to sensory neuron sensitization, including TRPV1 and TRPA1 (Akopian et al., 2007; Lishko et al., 2007; Lukacs et al., 2007). Our proteomic analysis also indicated upregulation of two neuropeptide precursors. The upregulation of CGRP precursor in the first $24 \mathrm{~h}$ of DRG culture is consistent with increases in CGRP in cultured trigeminal neurons and in some models of nerve injury (Kuris et al., 2007; Zheng et al., 2008). Previous studies have shown that, in the SNL model, the number of CGRP-positive neurons in injured ganglia was unchanged $24 \mathrm{~h}$ after injury (Lee et al., 2001) and substantially decreased at $7 \mathrm{~d}$ (Fukuoka et al., 1998; Lee et al., 2001; Hammond et al., 2004). VGF upregulation in DRG after nerve injury has been detected previously by microarray analysis (Costigan et al., 2002; Wang et 

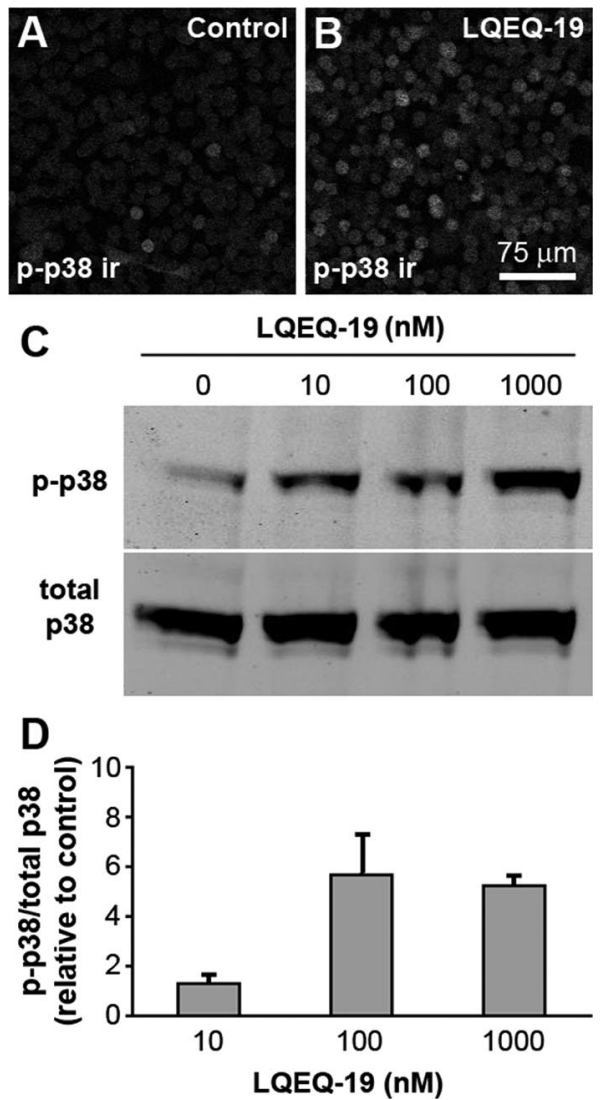

Figure 9. Treatment of BV-2 microglial cells with LQEQ-19 resulted in increased p38 phosphorylation. $A, B$, The number of phospho-p38-positive (p-p38) cells is increased after incubation of the cells with LQEQ-19 $(1 \mu \mathrm{m})$ for $2 \mathrm{~min}$. C, D, Dose-dependent increase in the relative levels of phospho-p38 after LQEQ-19 treatment. In $\boldsymbol{D}$, relative phospho-p38 was expressed as phospho-p38/total p38 and normalized relative to control values. The data represent averages of three experiments.

al., 2002; Valder et al., 2003) and was described recently in the spared nerve injury model (Moss et al., 2008).

\section{Upregulation of VGF after nerve injury and inflammation}

The increase in VGF levels in cultured DRG neurons was confirmed by Western blot and immunocytochemical analysis. This increase was paralleled by VGF upregulation in the SNL model of nerve injury. Within 24 h of SNL, VGF-IR was present in nearly all injured L5 and over half of uninjured L4 DRG neurons. The time course and level of upregulation clearly distinguish VGF from other neuropeptides known to be increased after nerve injury (Zhang et al., 1995; Fukuoka et al., 1998; Shortland et al., 2006). For example, $1 \mathrm{~d}$ after SNL, galanin was present in $\sim 40 \%$ of injured L5 DRG neurons and NPY was nearly absent, whereas the levels of both peptides were unchanged in uninjured L4 neurons (Shortland et al., 2006). VGF labeling colocalized with both TrkA and P2X3 labeling, suggesting that the factors governing VGF induction are not restricted to the NGF- or GDNFdependent subsets of sensory neurons. The rapid increase in VGF levels after SNL in both injured and uninjured sensory neurons and its persistence $7 \mathrm{~d}$ after the nerve injury are consistent with involvement of VGF in both the development and maintenance of nerve-injury-induced hypersensitivity. Within $24 \mathrm{~h}$ of SNL, injured myelinated and uninjured unmyelinated fibers develop spontaneous activity (for review, see Ringkamp and Meyer, 2005). The increased VGF expression in injured large neurons and uninjured small neurons suggests that increased release of VGF peptides from spontaneously active fibers may contribute to abnormal nociceptive processing in dorsal horn during the development of hypersensitivity. Moreover, VGF upregulation in large neurons persists $7 \mathrm{~d}$ after injury, consistent with continued contribution of large afferents to the maintenance of hypersensitivity (Ossipov et al., 2000; Sun et al., 2001).

Because VGF is a putative neuropeptide precursor (Levi et al., 2004), VGF-derived peptides are likely transported to the central terminals of DRG neurons. Therefore, VGF upregulation in DRG after SNL was expected to result in increased levels of VGF-IR within the superficial dorsal horn of spinal cord. Quantitative analysis in spinal cord demonstrated a significant increase in VGF-IR ipsilateral to SNL, and the increased colocalization of VGF- and CGRP-IR in superficial dorsal horn is consistent with elevated VGF levels within central terminals of sensory neurons. Therefore, increased spinal release of VGF peptides from sensory neurons may provide an early signal for peripheral nerve injury. Increased VGF expression after nerve injury has also been shown in spinal neurons (Moss et al., 2008), suggesting additional functions of VGF peptides in spinal plasticity.

The number of VGF-IR DRG neurons also increased after sham surgery but to a level significantly lower than SNL. This increase is likely attributable to tissue damage at the surgical site. The sham surgery includes removal of the vertebral transverse process and overlaying muscles, causing inflammation and injury to fibers innervating these tissues. Consistent with tissue damage after sham surgery, ATF3 expression was reported in $40 \%$ of sham L5 DRG 1 and $14 \mathrm{~d}$ after surgery (Shortland et al., 2006). We also observed an inflammation-induced increase in the number of VGF-positive neurons after hindpaw injection of CFA. Together, these results suggest that VGF expression in sensory neurons may be regulated by a spectrum of manipulations, which include varying degrees of inflammation and nerve injury.

\section{VGF peptides evoke thermal hyperalgesia through activation of microglial p38 MAPK}

The 617 aa sequence of VGF contains nearly a dozen potential cleavage sites. Functional effects have been reported for several potential proteolytic products contained within the C-terminal 62 aa portion of VGF (Alder et al., 2003; Succu et al., 2005). Recently, TLPQ-21, a VGF-derived peptide located immediately upstream from AQEE-30 within the VGF sequence, was shown to modulate inflammatory pain (Rizzi et al., 2008), and TLPQ-62, a peptide that includes both TLPQ-21 and AQEE-30, produced mechanical allodynia when administered intrathecally in rat (Moss et al., 2008). Our observations of dose-dependent thermal hyperalgesia evoked by intrathecal injection of AQEE-30 and LQEQ-19 provide additional evidence for a role of VGF peptides in nociceptive processing. Notably, the hyperalgesia evoked by VGF peptides exceeded in magnitude and duration the effect of NMDA in the same experimental paradigm (Kitto et al., 1992; Roberts et al., 2005). Although the tail-withdrawal paradigm used in our studies is a measure of acute hyperalgesia rather than hypersensitivity associated with persistent pain, Moss et al. (2008) demonstrated TLPQ-62-induced mechanical and cold allodynia, consistent with a role of VGF peptides in nerve injuryinduced hypersensitivity.

The signaling mechanisms of VGF-derived peptides are completely uncharacterized. Therefore, we examined several signaling pathways for their involvement in the spinal effects of AQEE-30 and LQEQ-19. The thermal hyperalgesia was inhibited dose dependently by the potent and selective p38 MAPK inhibi- 
tor SB202190. The activation of p38 by intrathecal injection of LQEQ-19 was confirmed by immunohistochemistry. LQEQ-19dependent p38 phosphorylation was seen predominantly in spinal microglia, and LQEQ-19 induced $\mathrm{p} 38$ phosphorylation in the microglial cell line BV-2. These findings suggest that AQEE-30 and LQEQ-19 may act directly on spinal microglia and contribute to microglial activation. It remains to be determined whether the longer C-terminal peptide TLPQ-62 also mediates p38 activation in spinal microglia.

Spinal microglia participate in the development of inflammatory and nerve injury-induced hypersensitivity in part through the activation of p38. Several mediators have been implicated in the mechanisms of p38 activation, including TNF $\alpha$, MCP-1, and fractalkine (Svensson et al., 2005; Zhang and De Koninck, 2006; Clark et al., 2007; Zhang et al., 2007; Zhuang et al., 2007; Milligan et al., 2008). Our results suggest that VGF peptides released from sensory neurons may also participate in activation of spinal microglia. Under normal conditions, VGF levels in sensory neurons are low, suggesting limited contribution to acute pain signaling. After nerve injury or inflammation, the combination of rapid VGF upregulation and increased excitability of sensory neurons is likely to potentiate the release of VGF peptides within the dorsal horn, in which they would be able to activate microglial p38.

It is presently unclear which functionally relevant VGF peptides are produced in vivo in sensory neurons and spinal cord. Candidates include TLPQ-62 and shorter fragments derived from it (i.e., TLPQ-21, AQEE-30, and LQEQ-19). The excitatory effects of TLPQ-62 on dorsal horn neurons may be underlined by microglia-dependent sensitization after action of the C-terminal portion of TLPQ-62 (i.e., AQEE-30 and LQEQ-19) as well as by activity of its $\mathrm{N}$ terminus (i.e., TLPQ-21), analogous to the effects in hippocampal slices, which were not mimicked by the C-terminal peptides (Bozdagi et al., 2008; Moss et al., 2008). The pattern of VGF processing can vary among different cell types and sometimes even within the same cell type (Brancia et al., 2005). Therefore, differential proteolytic processing of VGF within sensory neurons after different types of tissue damage may generate signaling peptides with distinct contributions to spinal pain mechanisms.

In conclusion, this study contributes to the increasing body of evidence for a role of VGF in neuroplasticity and provides the first description of a signaling pathway activated by VGF peptides. Our results suggest a novel action of VGF peptides as potential neuro-glial messengers after nerve injury and inflammation, a discovery driven by proteomic differential expression analysis and validated through anatomical and functional experiments.

\section{References}

Akopian AN, Ruparel NB, Jeske NA, Hargreaves KM (2007) Transient receptor potential TRPA1 channel desensitization in sensory neurons is agonist dependent and regulated by TRPV1-directed internalization. J Physiol 583:175-193.

Alder J, Thakker-Varia S, Bangasser DA, Kuroiwa M, Plummer MR, Shors TJ, Black IB (2003) Brain-derived neurotrophic factor-induced gene expression reveals novel actions of VGF in hippocampal synaptic plasticity. J Neurosci 23:10800-10808.

Boyle DL, Jones TL, Hammaker D, Svensson CI, Rosengren S, Albani S, Sorkin L, Firestein GS (2006) Regulation of peripheral inflammation by spinal p38 MAP kinase in rats. PLoS Med 3:e338.

Bozdagi O, Rich E, Tronel S, Sadahiro M, Patterson K, Shapiro ML, Alberini CM, Huntley GW, Salton SR (2008) The neurotrophin-inducible gene Vgf regulates hippocampal function and behavior through a brainderived neurotrophic factor-dependent mechanism. J Neurosci 28:9857-9869.
Brancia C, Nicolussi P, Cappai P, La Corte G, Possenti R, Ferri GL (2005) Differential expression and seasonal modulation of VGF peptides in sheep pituitary. J Endocrinol 186:97-107.

Campbell JN, Meyer RA (2006) Mechanisms of neuropathic pain. Neuron 52:77-92.

Chaplan SR, Bach FW, Pogrel JW, Chung JM, Yaksh TL (1994) Quantitative assessment of tactile allodynia in the rat paw. J Neurosci Methods 53:55-63.

Clark AK, Yip PK, Grist J, Gentry C, Staniland AA, Marchand F, Dehvari M, Wotherspoon G, Winter J, Ullah J, Bevan S, Malcangio M (2007) Inhibition of spinal microglial cathepsin $\mathrm{S}$ for the reversal of neuropathic pain. Proc Natl Acad Sci U S A 104:10655-10660.

Costigan M, Befort K, Karchewski L, Griffin RS, D’Urso D, Allchorne A, Sitarski J, Mannion JW, Pratt RE, Woolf CJ (2002) Replicate highdensity rat genome oligonucleotide microarrays reveal hundreds of regulated genes in the dorsal root ganglion after peripheral nerve injury. BMC Neurosci 3:16.

Diviani D, Scott JD (2001) AKAP signaling complexes at the cytoskeleton. J Cell Sci 114:1431-1437.

Fukuoka T, Tokunaga A, Kondo E, Miki K, Tachibana T, Noguchi K (1998) Change in mRNAs for neuropeptides and the GABA(A) receptor in dorsal root ganglion neurons in a rat experimental neuropathic pain model. Pain 78:13-26.

Gabra BH, Kessler FK, Ritter JK, Dewey WL, Smith FL (2007) Decrease in $\mathrm{N}$-methyl-D-aspartic acid receptor-NR2B subunit levels by intrathecal short-hairpin RNA blocks group I metabotropic glutamate receptormediated hyperalgesia. J Pharmacol Exp Ther 322:186-194.

Goldstein AL, Hannappel E, Kleinman HK (2005) Thymosin beta4: actinsequestering protein moonlights to repair injured tissues. Trends Mol Med 11:421-429.

Hammond DL, Ackerman L, Holdsworth R, Elzey B (2004) Effects of spinal nerve ligation on immunohistochemically identified neurons in the L4 and L5 dorsal root ganglia of the rat. J Comp Neurol 475:575-589.

Hunsberger JG, Newton SS, Bennett AH, Duman CH, Russell DS, Salton SR, Duman RS (2007) Antidepressant actions of the exercise-regulated gene VGF. Nat Med 13:1476-1482.

Hylden JL, Wilcox GL (1981) Intrathecal substance P elicits a caudallydirected biting and scratching behavior in mice. Brain Res 217:212-215.

Inoue M, Ueda H (2000) Protein kinase C-mediated acute tolerance to peripheral mu-opioid analgesia in the bradykinin-nociception test in mice. J Pharmacol Exp Ther 293:662-669.

Irmen CP, Siegel SM, Carr PA (2008) Localization of SSeCKS in unmyelinated primary sensory neurons. J Brachial Plex Peripher Nerve Inj 3:8.

Jin SX, Zhuang ZY, Woolf CJ, Ji RR (2003) p38 mitogen-activated protein kinase is activated after a spinal nerve ligation in spinal cord microglia and dorsal root ganglion neurons and contributes to the generation of neuropathic pain. J Neurosci 23:4017-4022.

Karchewski LA, Gratto KA, Wetmore C, Verge VM (2002) Dynamic patterns of BDNF expression in injured sensory neurons: differential modulation by NGF and NT-3. Eur J Neurosci 16:1449-1462.

Khasabova IA, Harding-Rose C, Simone DA, Seybold VS (2004) Differential effects of CB1 and opioid agonists on two populations of adult rat dorsal root ganglion neurons. J Neurosci 24:1744-1753.

Kim SH, Chung JM (1992) An experimental model for peripheral neuropathy produced by segmental spinal nerve ligation in the rat. Pain 50:355-363.

Kitto KF, Haley JE, Wilcox GL (1992) Involvement of nitric oxide in spinally mediated hyperalgesia in the mouse. Neurosci Lett 148:1-5.

Kohno K, Izumi H, Uchiumi T, Ashizuka M, Kuwano M (2003) The pleiotropic functions of the Y-box-binding protein, YB-1. Bioessays 25:691-698.

Komatsu T, Sakurada C, Sasaki M, Sanai K, Tsuzuki M, Bagetta G, Sakurada S, Sakurada T (2007) Extracellular signal-regulated kinase (ERK) and nitric oxide synthase mediate intrathecal morphine-induced nociceptive behavior. Neuropharmacology 52:1237-1243.

Komori N, Takemori N, Kim HK, Singh A, Hwang SH, Foreman RD, Chung K, Chung JM, Matsumoto H (2007) Proteomics study of neuropathic and nonneuropathic dorsal root ganglia: altered protein regulation following segmental spinal nerve ligation injury. Physiol Genomics 29:215-230.

Kuris A, Xu CB, Zhou MF, Tajti J, Uddman R, Edvinsson L (2007) En- 
hanced expression of CGRP in rat trigeminal ganglion neurons during cell and organ culture. Brain Res 1173:6-13.

Laux T, Fukami K, Thelen M, Golub T, Frey D, Caroni P (2000) GAP43, MARCKS, and CAP23 modulate PI $(4,5) \mathrm{P}(2)$ at plasmalemmal rafts, and regulate cell cortex actin dynamics through a common mechanism. J Cell Biol 149:1455-1472.

Lee WT, Sohn MK, Park SH, Ahn SK, Lee JE, Park KA (2001) Studies on the changes of c-fos protein in spinal cord and neurotransmitter in dorsal root ganglion of the rat with an experimental peripheral neuropathy. Yonsei Med J 42:30-40.

Levi A, Ferri GL, Watson E, Possenti R, Salton SR (2004) Processing, distribution, and function of VGF, a neuronal and endocrine peptide precursor. Cell Mol Neurobiol 24:517-533.

Li KW, Miller S, Klychnikov O, Loos M, Stahl-Zeng J, Spijker S, Mayford M, Smit AB (2007) Quantitative proteomics and protein network analysis of hippocampal synapses of CaMKIIalpha mutant mice. J Proteome Res 6:3127-3133

Lishko PV, Procko E, Jin X, Phelps CB, Gaudet R (2007) The ankyrin repeats of TRPV1 bind multiple ligands and modulate channel sensitivity. Neuron 54:905-918.

Lukacs V, Thyagarajan B, Varnai P, Balla A, Balla T, Rohacs T (2007) Dual regulation of TRPV1 by phosphoinositides. J Neurosci 27:7070-7080.

Lund TC, Anderson LB, McCullar V, Higgins L, Yun GH, Grzywacz B, Verneris MR, Miller JS (2007) iTRAQ is a useful method to screen for membranebound proteins differentially expressed in human natural killer cell types. J Proteome Res 6:644-653.

Maratou K, Wallace VC, Hasnie FS, Okuse K, Hosseini R, Jina N, Blackbeard J, Pheby T, Orengo C, Dickenson AH, McMahon SB, Rice AS (2009) Comparison of dorsal root ganglion gene expression in rat models of traumatic and HIV-associated neuropathic pain. Eur J Pain 13:387-398.

Mason MR, Lieberman AR, Grenningloh G, Anderson PN (2002) Transcriptional upregulation of SCG10 and CAP-23 is correlated with regeneration of the axons of peripheral and central neurons in vivo. Mol Cell Neurosci 20:595-615.

Milligan ED, Sloane EM, Watkins LR (2008) Glia in pathological pain: a role for fractalkine. J Neuroimmunol 198:113-120.

Moss A, Ingram R, Koch S, Theodorou A, Low L, Baccei M, Hathway GJ, Costigan M, Salton SR, Fitzgerald M (2008) Origins, actions and dynamic expression patterns of the neuropeptide VGF in rat peripheral and central sensory neurones following peripheral nerve injury. Mol Pain 4:62.

Ossipov MH, Lai J, Malan TP Jr, Porreca F (2000) Spinal and supraspinal mechanisms of neuropathic pain. Ann N Y Acad Sci 909:12-24.

Qu J, Liu GH, Huang B, Chen C (2007) Nitric oxide controls nuclear export of APE1/Ref-1 through S-nitrosation of cysteines 93 and 310. Nucleic Acids Res 35:2522-2532.

Raghavendra V, Tanga FY, DeLeo JA (2004) Complete Freunds adjuvantinduced peripheral inflammation evokes glial activation and proinflammatory cytokine expression in the CNS. Eur J Neurosci 20:467-473.

Ringkamp M, Meyer RA (2005) Injured versus uninjured afferents: Who is to blame for neuropathic pain? Anesthesiology 103:221-223.

Rizzi R, Bartolomucci A, Moles A, D’Amato F, Sacerdote P, Levi A, La Corte G, Ciotti MT, Possenti R, Pavone F (2008) The VGF-derived peptide TLQP-21: a new modulatory peptide for inflammatory pain. Neurosci Lett 441:129-133.

Roberts JC, Grocholski BM, Kitto KF, Fairbanks CA (2005) Pharmacodynamic and pharmacokinetic studies of agmatine after spinal administration in the mouse. J Pharmacol Exp Ther 314:1226-1233.

Sakurada S, Orito T, Sakurada C, Sato T, Hayashi T, Mobarakeh JI, Yanai K, Onodera K, Watanabe T, Sakurada T (2002) Possible involvement of tachykinin NK(1) and NMDA receptors in histamine-induced hyperalgesia in mice. Eur J Pharmacol 434:29-34.

Shilov IV, Seymour SL, Patel AA, Loboda A, Tang WH, Keating SP, Hunter CL, Nuwaysir LM, Schaeffer DA (2007) The Paragon Algorithm, a next generation search engine that uses sequence temperature values and feature probabilities to identify peptides from tandem mass spectra. Mol Cell Proteomics 6:1638-1655.

Shortland PJ, Baytug B, Krzyzanowska A, McMahon SB, Priestley JV, Averill S (2006) ATF3 expression in L4 dorsal root ganglion neurons after L5 spinal nerve transection. Eur J Neurosci 23:365-373.
Succu S, Mascia MS, Melis T, Sanna F, Melis MR, Possenti R, Argiolas A (2005) Pro-VGF-derived peptides induce penile erection in male rats: Involvement of paraventricular nitric oxide. Neuropharmacology 49:1017-1025.

Sun H, Ren K, Zhong CM, Ossipov MH, Malan TP, Lai J, Porreca F (2001) Nerve injury-induced tactile allodynia is mediated via ascending spinal dorsal column projections. Pain 90:105-111.

Sundaram M, Cook HW, Byers DM (2004) The MARCKS family of phospholipid binding proteins: regulation of phospholipase D and other cellular components. Biochem Cell Biol 82:191-200.

Svensson CI, Marsala M, Westerlund A, Calcutt NA, Campana WM, Freshwater JD, Catalano R, Feng Y, Protter AA, Scott B, Yaksh TL (2003) Activation of p38 mitogen-activated protein kinase in spinal microglia is a critical link in inflammation-induced spinal pain processing. J Neurochem 86:1534-1544.

Svensson CI, Schäfers M, Jones TL, Powell H, Sorkin LS (2005) Spinal blockade of TNF blocks spinal nerve ligation-induced increases in spinal P-p38. Neurosci Lett 379:209-213

Thakker-Varia S, Krol JJ, Nettleton J, Bilimoria PM, Bangasser DA, Shors TJ, Black IB, Alder J (2007) The neuropeptide VGF produces antidepressantlike behavioral effects and enhances proliferation in the hippocampus. J Neurosci 27:12156-12167.

Tsuda M, Mizokoshi A, Shigemoto-Mogami Y, Koizumi S, Inoue K (2004) Activation of p38 mitogen-activated protein kinase in spinal hyperactive microglia contributes to pain hypersensitivity following peripheral nerve injury. Glia 45:89-95.

Tsuda M, Inoue K, Salter MW (2005) Neuropathic pain and spinal microglia: a big problem from molecules in "small" glia. Trends Neurosci 28:101-107.

Valder CR, Liu JJ, Song YH, Luo ZD (2003) Coupling gene chip analyses and rat genetic variances in identifying potential target genes that may contribute to neuropathic allodynia development. J Neurochem 87:560-573.

Vasko MR, Guo C, Kelley MR (2005) The multifunctional DNA repair/ redox enzyme Ape1/Ref-1 promotes survival of neurons after oxidative stress. DNA Repair (Amst) 4:367-379.

Vulchanova L, Riedl MS, Shuster SJ, Buell G, Surprenant A, North RA, Elde R (1997) Immunohistochemical study of the P2X2 and P2X3 receptor subunits in rat and monkey sensory neurons and their central terminals. Neuropharmacology 36:1229-1242.

Wang H, Sun H, Della Penna K, Benz RJ, Xu J, Gerhold DL, Holder DJ, Koblan KS (2002) Chronic neuropathic pain is accompanied by global changes in gene expression and shares pathobiology with neurodegenerative diseases. Neuroscience 114:529-546.

Wenk HN, Brederson JD, Honda CN (2006) Morphine directly inhibits nociceptors in inflamed skin. J Neurophysiol 95:2083-2097.

White FA, Jung H, Miller RJ (2007) Chemokines and the pathophysiology of neuropathic pain. Proc Natl Acad Sci U S A 104:20151-20158.

Woolf CJ, Costigan M (1999) Transcriptional and posttranslational plasticity and the generation of inflammatory pain. Proc Natl Acad Sci U S A 96:7723-7730.

Wu HE, Sun HS, Cheng CW, Tseng LF (2006) p38 mitogen-activated protein kinase inhibitor SB203580 reverses the antianalgesia induced by dextro-morphine or morphine in the mouse spinal cord. Eur J Pharmacol 550:91-94.

Zhang J, De Koninck Y (2006) Spatial and temporal relationship between monocyte chemoattractant protein-1 expression and spinal glial activation following peripheral nerve injury. J Neurochem 97:772-783.

Zhang J, Shi XQ, Echeverry S, Mogil JS, De Koninck Y, Rivest S (2007) Expression of CCR2 in both resident and bone marrow-derived microglia plays a critical role in neuropathic pain. J Neurosci 27:12396-12406.

Zhang Q, Shi TJ, Ji RR, Zhang YZ, Sundler F, Hannibal J, Fahrenkrug J, Hökfelt T, Zhang Y (1995) Expression of pituitary adenylate cyclaseactivating polypeptide in dorsal root ganglia following axotomy: time course and coexistence. Brain Res 705:149-158.

Zheng LF, Wang R, Xu YZ, Yi XN, Zhang JW, Zeng ZC (2008) Calcitonin gene-related peptide dynamics in rat dorsal root ganglia and spinal cord following different sciatic nerve injuries. Brain Res 1187:20-32.

Zhuang ZY, Kawasaki Y, Tan PH, Wen YR, Huang J, Ji RR (2007) Role of the CX3CR1/p38 MAPK pathway in spinal microglia for the development of neuropathic pain following nerve injury-induced cleavage of fractalkine. Brain Behav Immun 21:642-651. 